\title{
Bathonian (Middle Jurassic) cyclostome bryozoans from the Polish Jura
}

\author{
MICHAŁ ZATOŃ \& PAUL D. TAYLOR
}

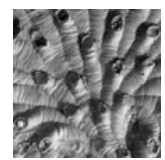

\begin{abstract}
Cyclostome bryozoan assemblages encrusting bivalve shells and oncoliths, as well as coming from the host sediment, are described from the Bathonian (Middle Jurassic) ore-bearing clays of the Polish Jura. In total, 16 species belonging to the genera Stomatopora, Proboscinopora?, Microeciella, Reptomultisparsa, Hyporosopora, Mecynoecia, Ceriocava and unidentified 'entalophorids' are described. Twelve taxa could not be determined with certainty to species level. Two species are described as new: Reptomultisparsa kawodrzanensis sp. nov. and Mecynoecia kaimi sp. nov. The diagnosis of Hyporosopora bugajensis Zaton \& Taylor, 2009a is emended. Combining the diversity data both from this and a previously published paper, a total of 29 species of cyclostome bryozoans are now known from the Bathonian of the Polish Basin, a stratigraphical stage during which the cyclostomes attained their peak-diversity for the Jurassic. This species richness is comparatively high, approaching the maximum recorded for a Jurassic assemblage, which is 33 species in the Bathonian of Normandy, France where the bryozoans are associated with sponge bioherms and hardgrounds as well as oncoliths and shells of bivalves and brachiopods. $\bullet$ Key words: Bryozoa, Cyclostomata, Middle Jurassic, Bathonian, Poland.
\end{abstract}

ZATOŃ, M. \& TAYLOR, P.D. 2010. Bathonian (Middle Jurassic) cyclostome bryozoans from the Polish Jura. Bulletin of Geosciences 85(2), 275-302 (16 figures). Czech Geological Survey, Prague. ISSN 1214-1119. Manuscript received February 1, 2010; accepted in revised form April 6, 2010; published online May 20, 2010; issued June 30, 2010.

Michat Zaton (corresponding author), University of Silesia, Faculty of Earth Sciences, Będzińska 60, 41-200 Sosnowiec, Poland; mzaton@wnoz.us.edu.pl•Paul D. Taylor, Natural History Museum, Department of Palaeontology, Cromwell Road, London SW7 5BD, United Kingdom; p.taylor@nhm.ac.uk

The Jurassic period was a crucial time for the evolution and radiation of post-Palaeozoic cyclostome bryozoans. Before the appearance in the latest Jurassic of the first cheilostomes (see Pohowsky 1973, Taylor 1994), the dominant bryozoan order today, cyclostomes underwent a distinct diversification during the Middle Jurassic with a peak in the Bathonian (Taylor \& Ernst 2008). However, our knowledge of the Middle Jurassic radiation of cyclostomes is imperfect and geographically constrained, as pointed out recently by $\mathrm{Za}$ toń \& Taylor (2009a).

Most data on the composition of Middle Jurassic bryozoan faunas comes from a few areas in Europe (France, Germany, England, and to a lesser extent Russia), plus some in North America (see Taylor \& Wilson 1999, Zatoń \& Taylor 2009a). Until recently Middle Jurassic bryozoans from Poland were scarcely known. However, two recent works have provided new data on bryozoan diversity in the Polish Basin during the Middle Jurassic. Taylor (2009) revised the Upper Bathonian-Lower Callovian bryozoans originally described by Reuss (1867) from Balin (southern Poland), and Zatoń \& Taylor (2009a) published a systematic account of the Upper
Bajocian-Bathonian bryozoans from the ore-bearing clays of the Polish Jura (south-central Poland).

The paper of Zaton \& Taylor (2009a) is notable because Upper Bajocian-Bathonian deposits outcropping in the Polish Jura consist of unconsolidated, soft siliciclastics, and thus the only potential hard substrates for bryozoan recruitment are hiatus concretions and occasional shells of invertebrates such as oysters. Oyster shells are patchily and unevenly distributed within the sequence and, as pointed out by Zaton \& Taylor (2009a), even when bryozoans are present on them, they are often not well-preserved due to encrustation by pyrite and siderite. Thus, any well-preserved bryozoans encrusting shells are worthy of attention. Recently, some heavily encrusted, large oncoliths have been discovered within the ore-bearing clays (see Zatoń \& Taylor 2009b), providing another potential source of cyclostome bryozoans.

The present paper provides new data on the cyclostome bryozoan fauna inhabiting the Polish Basin during the Bathonian, on the basis of colonies encrusting bivalve shells and newly discovered oncoliths. Additionally, some non-encrusting bryozoans collected from the clay samples are described. 


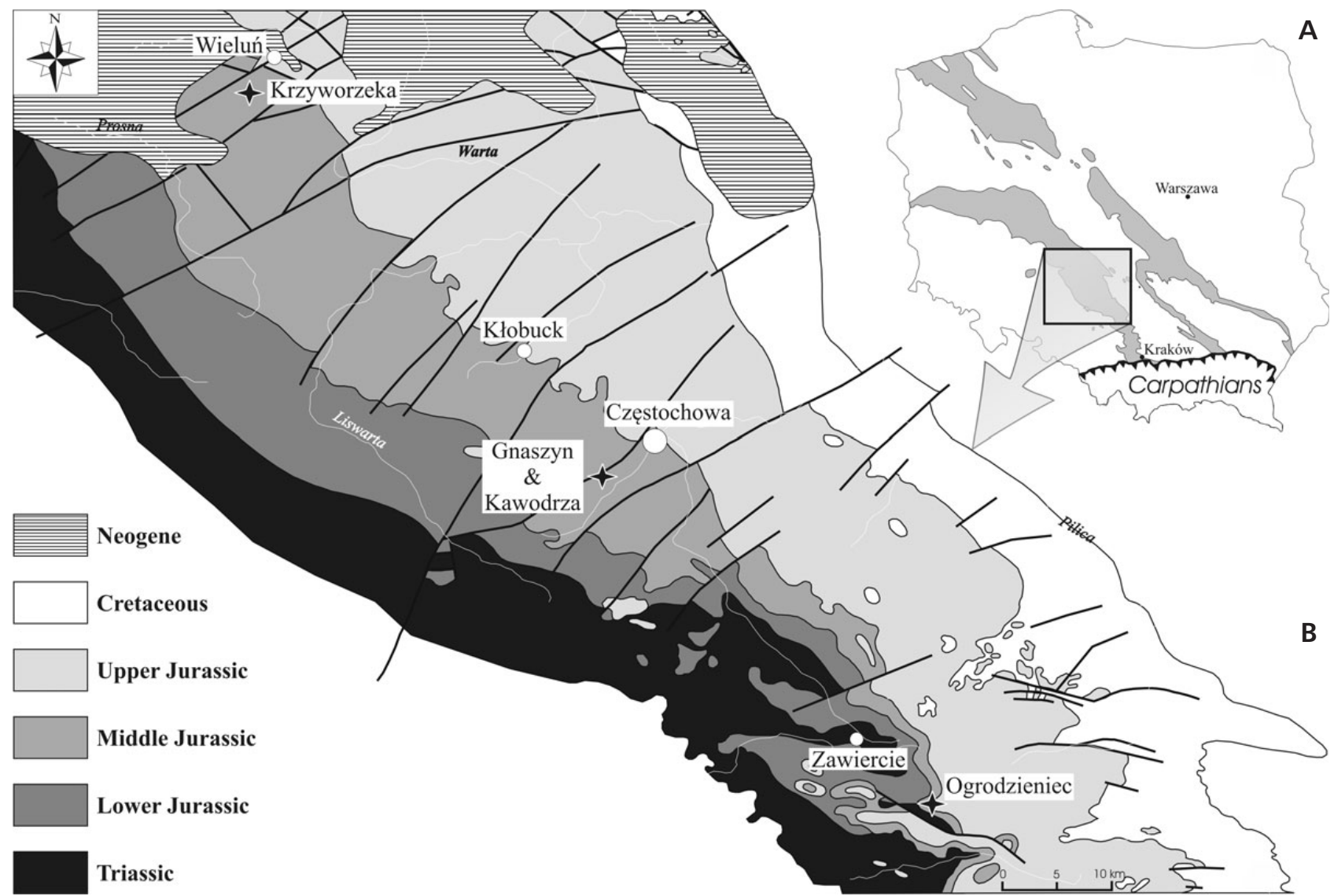

Figure 1. A - map of Poland with Jurassic deposits indicated (shaded areas) after removal of the Cenozoic cover. • B - geological map of the Polish Jura area with sampled localities indicated (asterisks) (adopted from Zatoń \& Taylor 2009a).

\section{Palaeogeographical and geological setting}

The Polish Jura is a monoclinal structure extending from the area of Kraków in the south to Wielun to the north (Fig. 1). During the Middle Jurassic, the territory of Poland was covered by an epicontinental sea and constituted the so-called Polish Basin, an eastern extension of the Mid-European epicontinental sea. The Polish Basin was surrounded by landmasses on almost all sides. It was bordered by the Fennoscandian Shield to the north, the Belorussian High and Ukrainian Shield to the east, the Bohemian Massif to the west, and the pre-Carpathian Landmass to the south (Dadlez 1989, Ziegler 1990). During the Aalenian, the basin was narrow and oriented south-east to north-west. During the Bathonian the basin widened, reaching its maximum in the Late Bathonian when almost the entire area of extra-Carpathian Poland was under the sea (see Matyja \& Wierzbowski 1998, 2006). Sedimentation was dominated by siliciclastics (e.g., Różycki 1953, Feldman-Olszewska 1997, Matyja \& Wierzbowski 2006).

Upper Bajocian and Bathonian deposits attain a thickness of about $180 \mathrm{~m}$ in the north and $85 \mathrm{~m}$ in the south of the Polish Jura (Matyja \& Wierzbowski 2006). They form a monotonous sequence consisting of black to dark-grey clays, siltstones and mudstones, intercalated with many isolated or horizon-forming carbonate (sideritic and calcitic) concretions, and are referred to as the Ore-Bearing Częstochowa Clay Formation (e.g., Dayczak-Calikowska et al. 1997, Kopik 1998, Majewski 2000, Matyja \& Wierzbowski 2006). The formation is thought to have been deposited in a generally quiet marine environment, below storm wave-base (see Matyja et al. 2006a, b, c), on an oxygenated sea-floor (Szczepanik et al. 2007, Marynowski et al. 2007, Zatoń et al. 2009). Sedimentation was relatively continuous, although pauses and erosional episodes are well-marked in the form of encrusted and bored hiatus concretions (e.g., Majewski 2000, Zatoń et al. 2006a, Zatoń \& Taylor 2009a), as well as encrusted oncoliths (Zatoń \& Taylor 2009b).

The ore-bearing clays are currently exposed in several active and abandoned brickyards, scattered across the entire area of the Polish Jura, and are especially famous for their diverse, abundant and well-preserved fossils (e.g., Gedl et al. 2003; Zatoń et al. 2007, 2009). The currently exposed deposits range from the Parkinsoni Zone of the Upper Bajocian to the Orbis Zone of the Upper Bathonian 
(e.g., Kopik 1998, 2006; Matyja \& Wierzbowski 2000; Matyja et al. 2006a, b, c; Zatoń 2007). The highest zone of the Upper Bathonian, the Discus Zone, has also been identified using dinoflagellate cysts in the northern and southern parts of the Polish Jura by Poulsen (1998) and Barski et al. (2004), respectively.

\section{Material, localities and methods}

The studied material consists of encrusting, uniserial to multiserial sheet-like, cone- and dome-shaped and erect bryozoan colonies from four localities situated in the Polish Jura (Fig. 1):

(1) Ogrodzieniec. The investigated material was collected from a small outcrop located south of Ogrodzieniec town centre (see Zatoń \& Taylor 2009b for details). Here, bryozoans were found to encrust large discoidal oncoliths. The ammonites [mainly parkinsoniids, including Parkinsonia (Oraniceras) gyrumbilica] found near the oncolithbearing horizon indicate that the oncoliths are not younger than Lower Bathonian Zigzag Zone, Macrescens Subzone. An attempt was made to separate the bryozoan colonies from the surfaces of the oncoliths using a needle. However, due to the nature of the cortical laminae, some of the encrusting colonies, especially those of uniserial stomatoporids, were prone to damage, and in some multiserial bereniciform colonies only fragments were recovered. In addition to stomatoporids and cerioporines, sheet-like bereniciform colonies were found on all $40 \mathrm{col}$ lected oncoliths. Of these, twelve colonies were fertile, but only eight could be detached for further study.

(2) Kawodrza Górna. This locality is situated near the city of Częstochowa (Fig. 1). Cyclostome bryozoans in the form of sheet-like colonies were collected in two active clay-pits ('Sowa' and 'Leszczyński'). In the 'Sowa' clay-pit, the specimens come from the higher part of the section, representing the lowermost Bathonian (Zigzag Zone, Convergens Subzone; see Matyja \& Wierzbowski 2000, Matyja et al. 2006a, Zatoń \& Marynowski 2006 for details). In the 'Leszczyński' clay-pit, the single studied colony was found in the topmost part of the section, dated as highest Lower Bathonian (Tenuiplicatus Zone; see Matyja \& Wierzbowski 2000, Matyja et al. 2006b for details). Sheet-like bryozoans from Kawodrza Górna were found either encrusting oyster shells attached to fossil wood ('Sowa' clay-pit) or a free bivalve shell ('Leszczyński' clay-pit). In total, 37 well-preserved colonies encrusting shells were identified. Twelve of these are fertile (i.e. possess gonozooids) and thus can be determined at least to the genus level.

(3) Gnaszyn Dolny. This locality is situated just north of Kawodrza Górna. Uniserial and multiserial, sheet-like bryozoan colonies have been found encrusting oyster shells at the active 'Gnaszyn' clay-pit (Fig. 1) where Middle to Upper Bathonian sediments are exposed (see Zatoń et al. 2006b, 2009; Matyja et al. 2006c; Szczepanik et al. 2007 for details). Bryozoan-encrusted oysters come from an interval representing the Middle Bathonian Morrisi Zone. They comprise 11 stomatoporid colonies and fragments, and 67 sheet-like colonies, of which only six are fertile.

(4) Krzyworzeka. This locality is situated in the northern part of the Polish Jura (Fig. 1). The clay sequence exposed here represents the Upper Bathonian (Hodsoni or Orbis-Discus zones) (see Poulsen 1998, Zatoń et al. 2006a for details). Erect, branching bryozoan colonies were found in a single fossiliferous lens within the host clays. Several tens of branch fragments were picked under a binocular microscope but only one was found to have a gonozooid.

Colonies were ultrasonically cleaned and examined in an uncoated state using a Philips XL30 environmental scanning electron microscope (ESEM) at the Faculty of Earth Sciences in Sosnowiec.

Bryozoans from the Ogrodzieniec, Kawodrza Górna and Gnaszyn Dolny localities are housed at the Faculty of Earth Sciences of the University of Silesia in Sosnowiec (catalogue numbers GIUS 8-3558-3575), while specimens from Krzyworzeka are housed at the Institute of Paleobiology of the Polish Academy of Sciences in Warsaw (catalogue number ZPAL Br 13).

\section{Systematic palaeontology}

Phylum Bryozoa Ehrenberg, 1831

Class Stenolaemata Borg, 1926

Order Cyclostomata Busk, 1852

Suborder Tubuliporina Milne-Edwards, 1838

Family Stomatoporidae Pergens \& Meunier, 1886

\section{Genus Stomatopora Bronn, 1825}

Type species. - Alecto dichotoma Lamouroux, 1821, Bathonian.

\section{Stomatopora bajocensis (d'Orbigny, 1850)}

Figure 2

1850 Alecto bajocensis; d'Orbigny, p. 288.

1867 Stomatopora bouchardi Haime, 1854. - Reuss, p. 2 (partim).

1963 Stomatopora bajocensis (d'Orbigny, 1850). - Illies, p. 74, pl. 7, figs 1, 2 .

1970 Stomatopora bajocensis (d'Orbigny, 1850). - Walter, p. 36 , pl. 1, fig 7 .

2009 Stomatopora bajocensis (d'Orbigny, 1850). - Taylor, p. 22. 

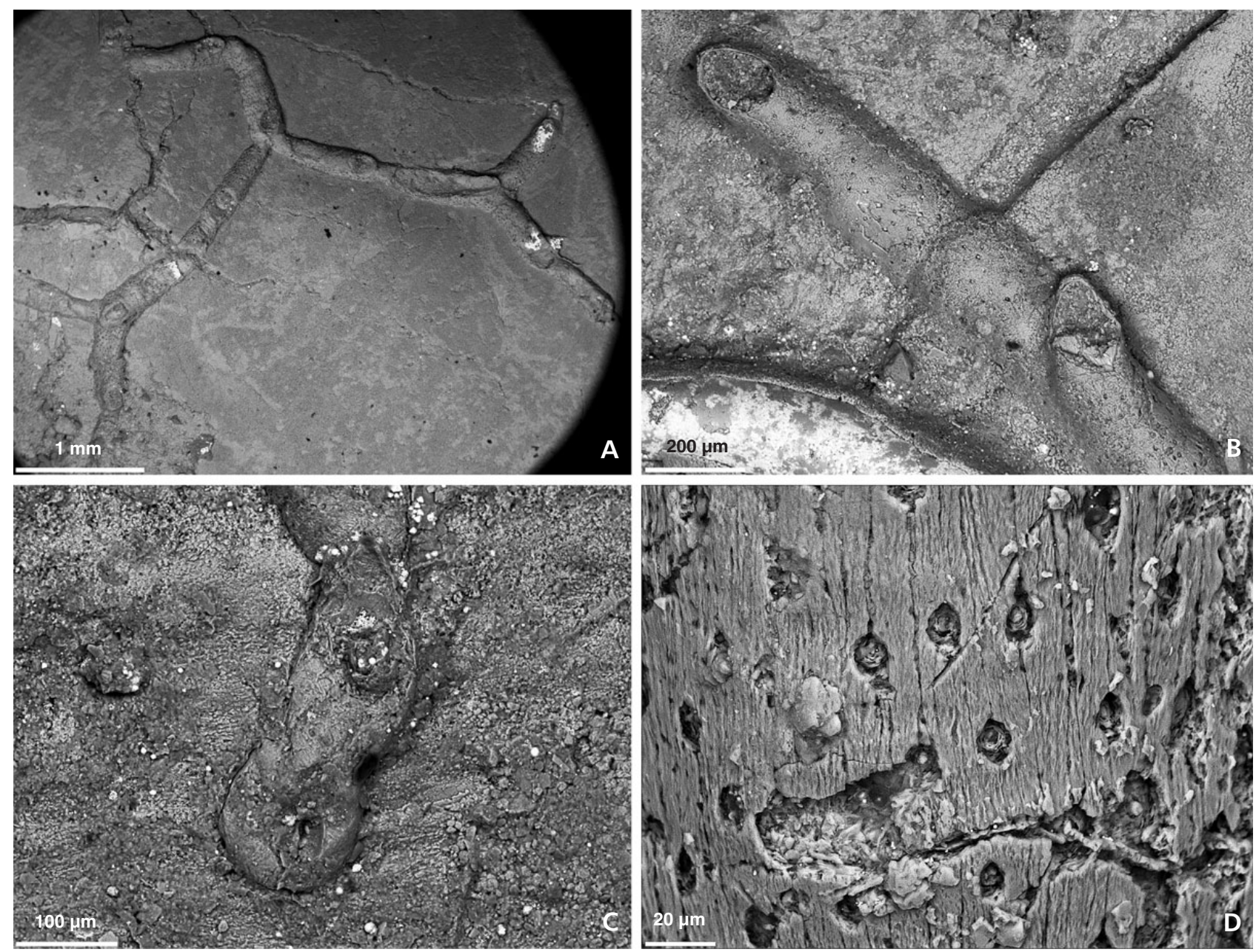

Figure 2. Stomatopora bajocensis (d'Orbigny, 1850), Middle Bathonian, Gnaszyn Dolny, Polish Jura. A, D - 3565/1, B - 3565/2, C - 3565/3. • A - colony. $\bullet \mathrm{B}-$ autozooids. $\bullet \mathrm{C}-$ ancestrula with damaged protoecium. $\bullet \mathrm{D}-$ pseudopores.

2009a Stomatopora bajocensis (d'Orbigny, 1850). - Zatoń $\&$ Taylor, p. 269, fig 2A.

Material. - Twelve fragmentary colonies encrusting oyster shells and two colonies originally encrusting an oncolith.

Measurements. - Transverse apertural diameter $=78$ to $116 \mu \mathrm{m}$; transverse peristomial diameter $=89-174 \mu \mathrm{m}$; longitudinal aperture diameter $=111-174 \mu \mathrm{m}$; longitudinal peristomial diameter $=133-232 \mu \mathrm{m}$; frontal wall length $=$ 592-1186 $\mu \mathrm{m}$; frontal wall width (proximal) $=92-205 \mu \mathrm{m}$; frontal wall width $($ distal $)=155-290 \mu \mathrm{m}$.

Description. - Colonies encrusting, uniserial with dichotomously bifurcating branches (Fig. 2A, B). Internodes comprising one to three autozooids. Ancestrula (Fig. 2C) short $(273 \mu \mathrm{m})$; protoecium slightly ovoidal in outline, $132 \mu \mathrm{m}$ in diameter, with scattered pseudopores; distal ancestrular tube short (144 $\mu \mathrm{m}$ in length), widening distally; aperture ovoidal in outline, $65 \mu \mathrm{m}$ in diameter. One budded auto- zooid prior to first bifurcation at an angle of $131^{\circ}$, succeeding bifurcations at lower angles $\left(95^{\circ}\right)$.

Autozooid frontal wall elongate, more or less distinctly widening distally. Apertures subcircular, slightly longitudinally elongate, with short preserved peristomes (Fig. 2B). Pseudopores scattered, broadly teardrop-shaped, pointed distally, $10 \mu \mathrm{m}$ wide (Fig. 2D).

Discussion. - As was pointed out by Taylor (2009), S. bajocensis (d'Orbigny) has a very similar colony-form to $S$. dichotomoides. However, it differs from the latter species in its narrower autozooid frontal walls, which are 92-290 $\mu \mathrm{m}($ mean $=145 \mu \mathrm{m}, \mathrm{n}=9)$ in S. bajocensis compared to 290-320 $\mu \mathrm{m}$ in S. dichotomoides (see Hara \& Taylor 2009). The general features of the colonies described here are similar to those of $S$. bajocensis encrusting hiatus concretions from the Middle and Upper Bathonian of the Polish Jura (Zatoń \& Taylor 2009a). Autozooid frontal wall width, one of the most important morphometric characters distinguishing species within a genus (e.g., Hara \& Taylor 

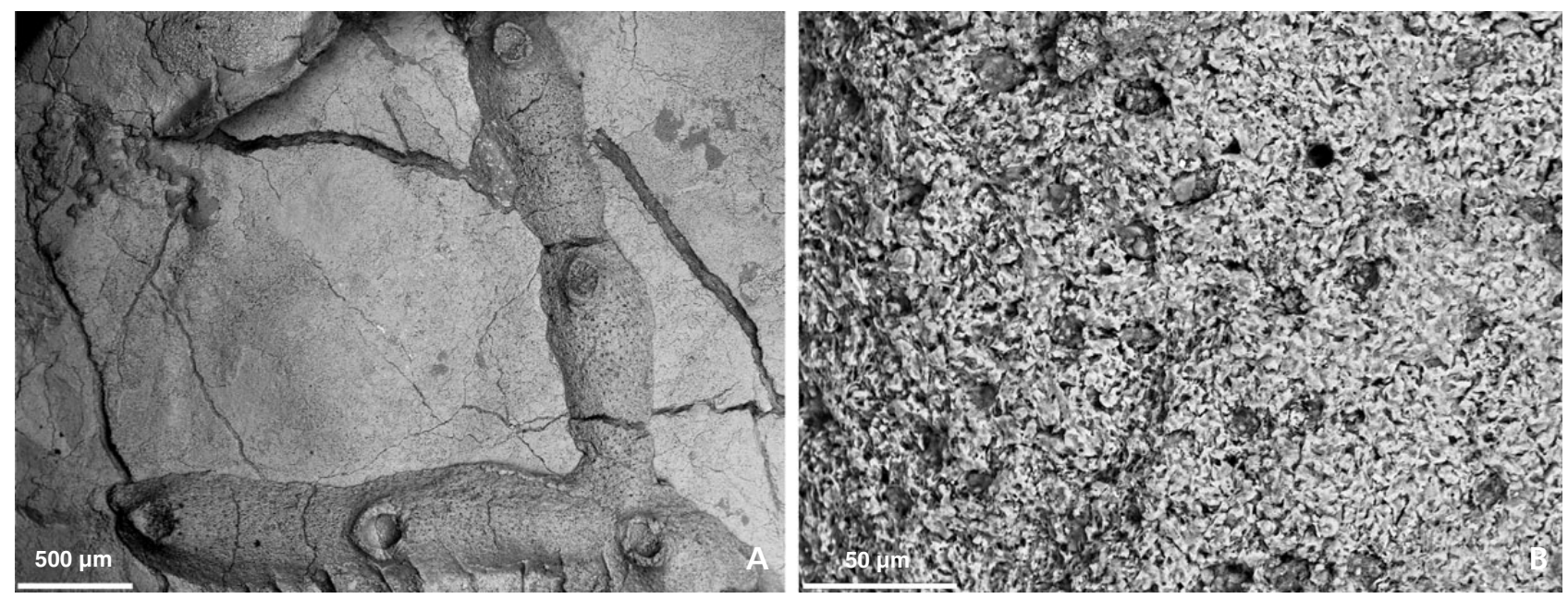

Figure 3. Stomatopora sp., Lower Bathonian, Ogrodzieniec, Polish Jura, GIUS 8-3569/1. • A - bifurcating branches and autozooids. • B - pseudopores in corroded frontal wall.

2009), generally falls within the range of S. bajocensis described by Zatoń \& Taylor (2009a), but some higher values are also recorded in the colonies described in the present paper.

Occurrence. - Lower Bathonian of Ogrodzieniec and Kawodrza Górna, and Middle Bathonian of Gnaszyn Dolny, Polish Jura.

\section{Stomatopora sp.}

Figure 3

Material. - Two fragmentary colonies originally encrusting oncoliths, only one of which could be retrieved for SEM study.

Measurements. - Transverse apertural diameter $=104$ to $149 \mu \mathrm{m}$; longitudinal aperture diameter $=134-179 \mu \mathrm{m}$; frontal wall length $=955-1164 \mu \mathrm{m}$; frontal wall width 462-507 $\mu \mathrm{m}$.

Description. - Colony encrusting with uniserial branches, bifurcating dichotomously at angles of $\mathrm{ca} 80^{\circ}$. Ancestrula not preserved. Autozooids large and elongate, 2-3 per internode. Apertures subcircular to longitudinally elongate (Fig. 3A). Pseudopores subcircular, 9.3 to $11.6 \mu \mathrm{m}$ in diameter (Fig. 3B).

Remarks. - The studied colony is primarily distinguished by its large autozooids, the frontal walls being well over $300 \mu \mathrm{m}$ in width. A very similar colony was recently described from the Kimmeridgian of Poland by Hara \& Taylor (2009) under the name Stomatopora sp. Both colonies have autozooids of similar width and subcircular pseudo- pores, but the Bathonian colony has wider and shorter apertures. The large autozooids of this species contrast with S. bajocensis, $S$. dichotomoides and S. corallina, in which autozooid width is noticeably smaller (see Taylor 2009, Hara \& Taylor 2009, Zatoń \& Taylor 2009a). However, the Stomatopora described here possesses smaller autozooids than the most robust Jurassic species, S. recurva (see Zaton \& Taylor 2009a).

Occurrence. - Lower Bathonian of Ogrodzieniec, Polish Jura.

\section{Genus Proboscinopora Pitt \& Taylor, 1990}

Type species. - Proboscina divisi Vine, 1893, Middle Jurassic, Cornbrash (probably basal Callovian), Thrapston, Northamptonshire, England.

\section{Proboscinopora? sp.}

Figure 4

Material. - Nine colonies have been found encrusting oncoliths, one studied using SEM.

Measurements. - Branch width: $1343 \mu \mathrm{m}$; transverse apertural diameter: 196-343 $\mu \mathrm{m}$; pseudopore diameter: 11.6-15 $\mu \mathrm{m}$.

Description. - Colony encrusting, consisting of narrow, oligoserial, ribbon-like branches (Fig. 4A). Autozooids short, up to three across a branch, some preserving quite long, erect peristomes. Autozooid apertures spaced at varying distances, subcircular to longitudinally elongate. Pseudopores densely spaced, subcircular (Fig. 4B). 

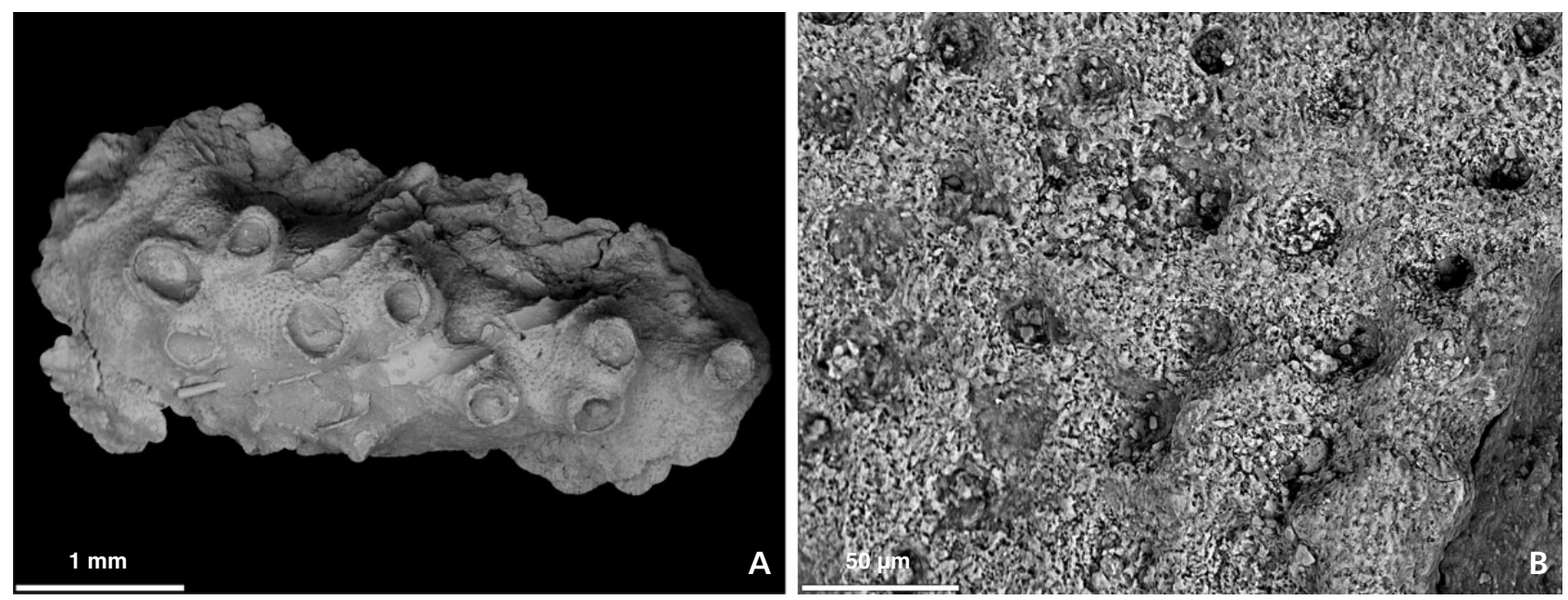

Figure 4. Proboscinopora? sp., Lower Bathonian, Ogrodzieniec, Polish Jura, GIUS 8-3570/2. A - oligoserial branch fragment with short autozooids. - B - pseudopores in corroded frontal wall.

Discussion. - Cyclostome species with encrusting colonies in the form of bifurcating, ribbon-like oligoserial branches and lacking basal gonozooids, as in the material studied here, are placed in the genus Proboscinopora Pitt \& Taylor, 1990. However, as the colonies encrusting oncoliths are incomplete, it is uncertain whether they possessed basal gonozooids and thus belong to the genus Oncousoecia which has a similar colony-form. The short autozooids with closely associated apertures and subcircular pseudopores distinguish this species from the Proboscinopora? sp. described from the Middle Bathonian of the Polish Jura by Zatoń \& Taylor (2009a).

Occurrence. - Lower Bathonian of Ogrodzieniec, Polish Jura.

Family Oncousoeciidae Canu, 1918

\section{Genus Microeciella Taylor and Sequeiros, 1982}

Type species. - Microeciella beliensis Taylor \& Sequeiros, 1982; Lower Jurassic, Toarcian, Belchite, Spain.

Microeciella aff. annae Zatoń \& Taylor, 2009a Figure 5

Material. - Two colonies encrusting oyster shells attached to the same wood substrate.

Measurements. - Transverse apertural diameter $=63$ to $116 \mu \mathrm{m}$; longitudinal aperture diameter $=63-151 \mu \mathrm{m}$; frontal wall length $=280-443 \mu \mathrm{m}$; frontal wall width $=$ 101-151 $\mu \mathrm{m}$; gonozooid total length $=506-721 \mu \mathrm{m}$; gonozooid brood chamber length $=443-465 \mu \mathrm{m}$; gonozooid width $=314-316 \mu \mathrm{m} ;$ ooeciopore length $=27-41 \mu \mathrm{m}$; ooeciopore width $=45-51 \mu \mathrm{m}$; pseudopore length $=6.4$ to $11.6 \mu \mathrm{m}$; pseudopore width $=5.2-5.8 \mu \mathrm{m}$.

Description. - Colonies encrusting, multiserial, unilamellar, discoidal, bereniciform (Fig. 5A, E). Early astogeny not visible. Autozooids short, narrow, distally more convex; zooidal boundaries distinct. Peristomes tapering distally, slightly salient. Apertures subcircular to longitudinally elongate (Fig. 5B). Pseudopores oval to wide teardrop shaped, pointed distally, sparse (Fig. 5H).

Gonozooids represented by one example in each colony, both crushed. Proximal frontal walls indistinguishable from autozooids. Brood chamber (i.e. distal, inflated part of gonozooid) ovoidal, only slightly longer than wide, convex, lateral edges indented by two neighbouring autozooids. Roof densely pseudoporous (Fig. 5C, F). Ooeciopores terminal, located beyond distal margin of brood chamber, subcircular to transversely oval, smaller than autozooid apertures. Ooeciostome short, upright, tapering distally (Fig. 5D, G).

Remarks. - Both colonies have been found encrusting shells attached to the same woody substrate and thus may be considered as nearly contemporaneous.

With respect to some of the skeletal features, the colonies described here are similar to the Lower Bathonian species Microeciella annae, named recently by Zaton \&

Figure 5. Microeciella aff. annae Zatoń \& Taylor, 2009a, Lower Bathonian, Kawodrza Górna, Polish Jura. • A-D - GIUS 8-3559/1, E-H - GIUS 8-3559/2. • A, E - colony. • B - autozooids. $\bullet$ C, F -gonozooids. $\bullet$ D, G - terminal ooeciopores (arrowed). $\bullet$ H - pseudopores. 

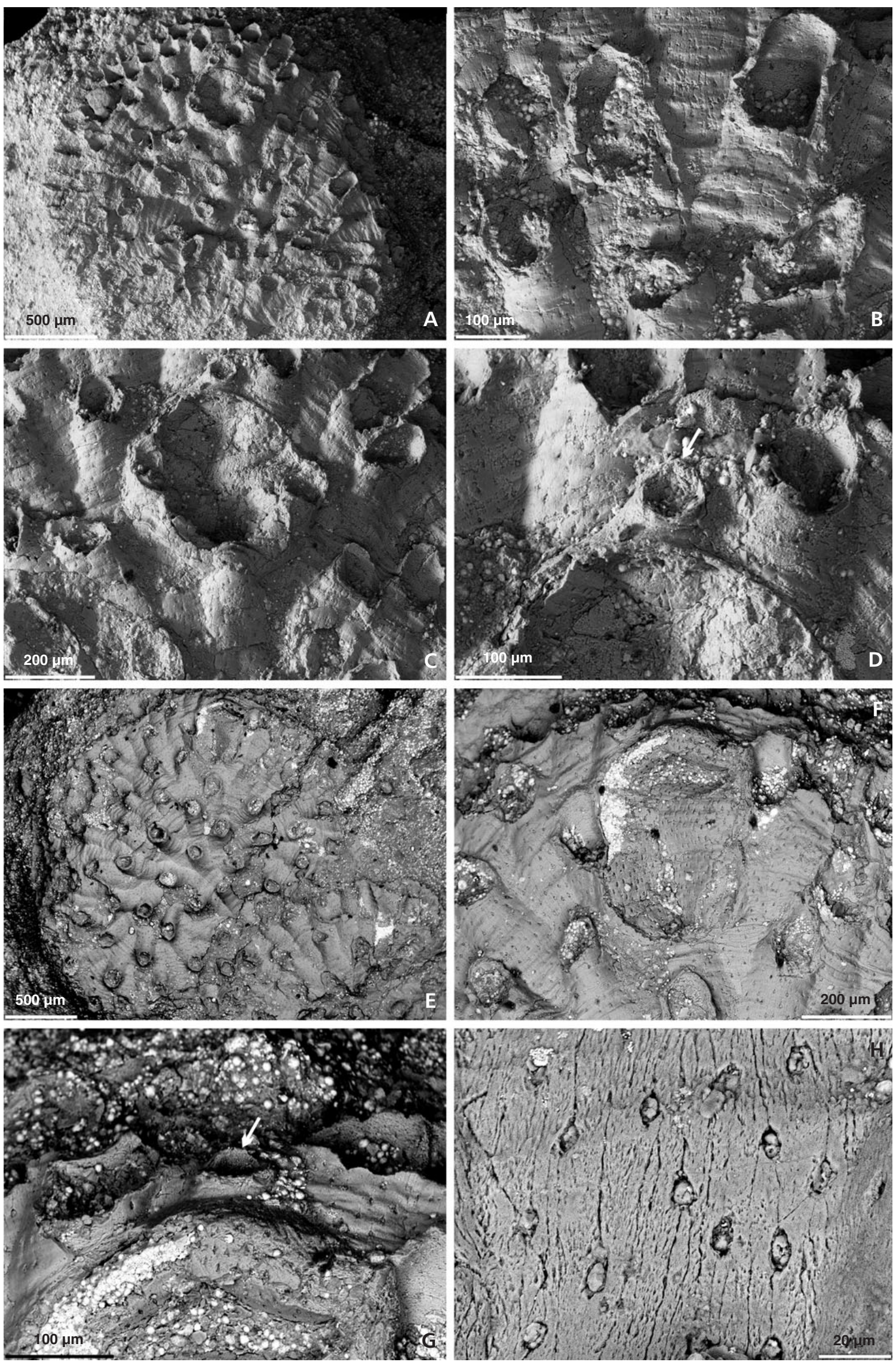
Taylor (2009a). As in the case of M. annae, the colonies described here possess terminal ooeciopores on short and straight ooeciostomes. This feature alone distinguishes M. annae and the species described here from the other Jurassic species of Microeciella (see Taylor \& Wilson 1999, Zatoń \& Taylor 2009a), in which the ooeciopore is subterminal and is located within the margin of the dilated brood chamber. It is worth noting here that a recent species of Microeciella, Microeciella suborbicularis (Hincks, 1880), also possesses a terminal ooeciopore (see Taylor \& Zatoń 2008).

Although the brood chambers of the species described here and the type material of $M$. annae are quite similar in overall shape, they are nearly twice as large in the latter. Also autozooid length is significantly smaller in the colonies described here (the mean value in the two colonies is 356 and $359 \mu \mathrm{m}$; $c f$. $613 \mu \mathrm{m}$ in $M$. annae). However, autozooid frontal wall width in the material described here falls within the range of width seen in type material of M. annae. Another difference is the size of the ooeciopore, which is two times larger in type $M$. annae. The pseudopores are slightly shorter and wider in the material described here, but of generally similar shape.

In conclusion, although the colonies described here differ quantitatively in some skeletal features from the types of M. annae, general morphological similarity (e.g. brood chamber shape and terminally located ooeciopore, pseudopore morphology) suggest a close affinity. The geological ages of $M$. annae and $M$. aff. annae are similar, coming from the same ammonite zone, but $M$. aff. annae is slightly older (Zigzag Zone, Convergens Subzone). Further material is needed to determine whether they belong to the same, intraspecifically-variable species, or different but phylogenetically very closely-related species.

Occurrence. - Lowermost Bathonian of Kawodrza Górna, Polish Jura.

\section{Microeciella aff. mokrskoensis Zatoń \& Taylor, 2009a Figure 6}

Material. - Two fertile colonies encrusting a bivalve shell and an oncolith.

Measurements. - Transverse apertural diameter $=78$ to $127 \mu \mathrm{m}$; longitudinal aperture diameter $=80-176 \mu \mathrm{m}$; frontal wall length $=588-863 \mu \mathrm{m}$; frontal wall width $=$ 118-196 $\mu \mathrm{m}$; gonozooid total length $=\sim 720-1274 \mu \mathrm{m}$; gonozooid brood chamber length $=598-706 \mu \mathrm{m}$; gonozooid width $=\sim 437-549 \mu \mathrm{m}$; ooeciopore length $=78 \mu \mathrm{m}$; ooeciopore width $=87 \mu \mathrm{m}$; pseudopore length $=7.9-13.4 \mu \mathrm{m}$; pseudopore width $=4.5-6.8 \mu \mathrm{m}$.
Description. - Colony encrusting, multiserial, unilamellar, bereniciform, discoidal in shape, partly encrusted with pyrite (Fig. 6A). Autozooids short, elongate, with frontal walls flat proximally and slightly convex distally; zooidal boundaries visible as grooves. Peristomes salient, slightly tapering distally. Apertures subcircular to longitudinally elongated, some closed by terminal diaphragms (Fig. 6B, F). Pseudopores sparse, teardrop-shaped, elongated and pointed distally, occasionally oval (Fig. 6D).

Gonozooids numbering one per colony. Proximal frontal wall flat, indistinguishable from that of autozooid. Brood chamber convex, two times longer than gonozooid proximal frontal wall, ovoidal, spindle-shaped, longer than wide, greatest width attained mid-length. Roof densely pseudoporous, margin indented by neighbouring autozooids. Ooeciopore circular, slightly smaller than an autozooid aperture, subterminal (Fig. 6C, E).

Remarks. - With respect to skeletal features and their dimensions, both colonies from the Lower Bathonian of Ogrodzieniec and Kawodrza Górna, encrusting oncolithic and shelly substrate respectively, are very similar and thus identified as the same species. With regard to gonozooid morphology, this species is reminiscent of M. mokrskoensis Zaton \& Taylor, 2009a, originally described encrusting uppermost Bajocian hiatus concretions in the Polish Jura. The gonozooid of $M$. aff. mokrskoensis is also elongated with the ooeciopore located subterminally, and the pseudopores are similarly teardrop-shaped, some of them elongated. However, zooidal dimensions of the new material are slightly greater than those of M. mokrskoensis (see Zaton \& Taylor 2009a), suggesting that they represent a different but related species.

Occurrence. - Lower Bathonian of Ogrodzieniec and Kawodrza Górna, Polish Jura.

\section{Microeciella aff. maleckii Zatoń \& Taylor, 2009a} Figure 7

Material. - Two incomplete, fertile colonies originally encrusting oncoliths.

Measurements. - Transverse apertural diameter $=83$ to $103 \mu \mathrm{m}$; longitudinal aperture diameter $=92-133 \mu \mathrm{m}$; frontal wall length $=650-919 \mu \mathrm{m}$; frontal wall width $=$ 161-230 $\mu \mathrm{m}$; gonozooid total length $=933-1414 \mu \mathrm{m}$; gonozooid brood chamber length $=623-850 \mu \mathrm{m}$; gonozooid width $=532-759 \mu \mathrm{m}$; ooeciopore length $=55.7 \mu \mathrm{m}$; ooeciopore width $=51-92 \mu \mathrm{m}$; pseudopore length $=8.7-15 \mu \mathrm{m}$; pseudopore width $=5.2-9.3 \mu \mathrm{m}$.

Description. - Colony encrusting, sheet-like, bereniciform, multiserial, unilamellar (Fig. 7A). Autozooids of 

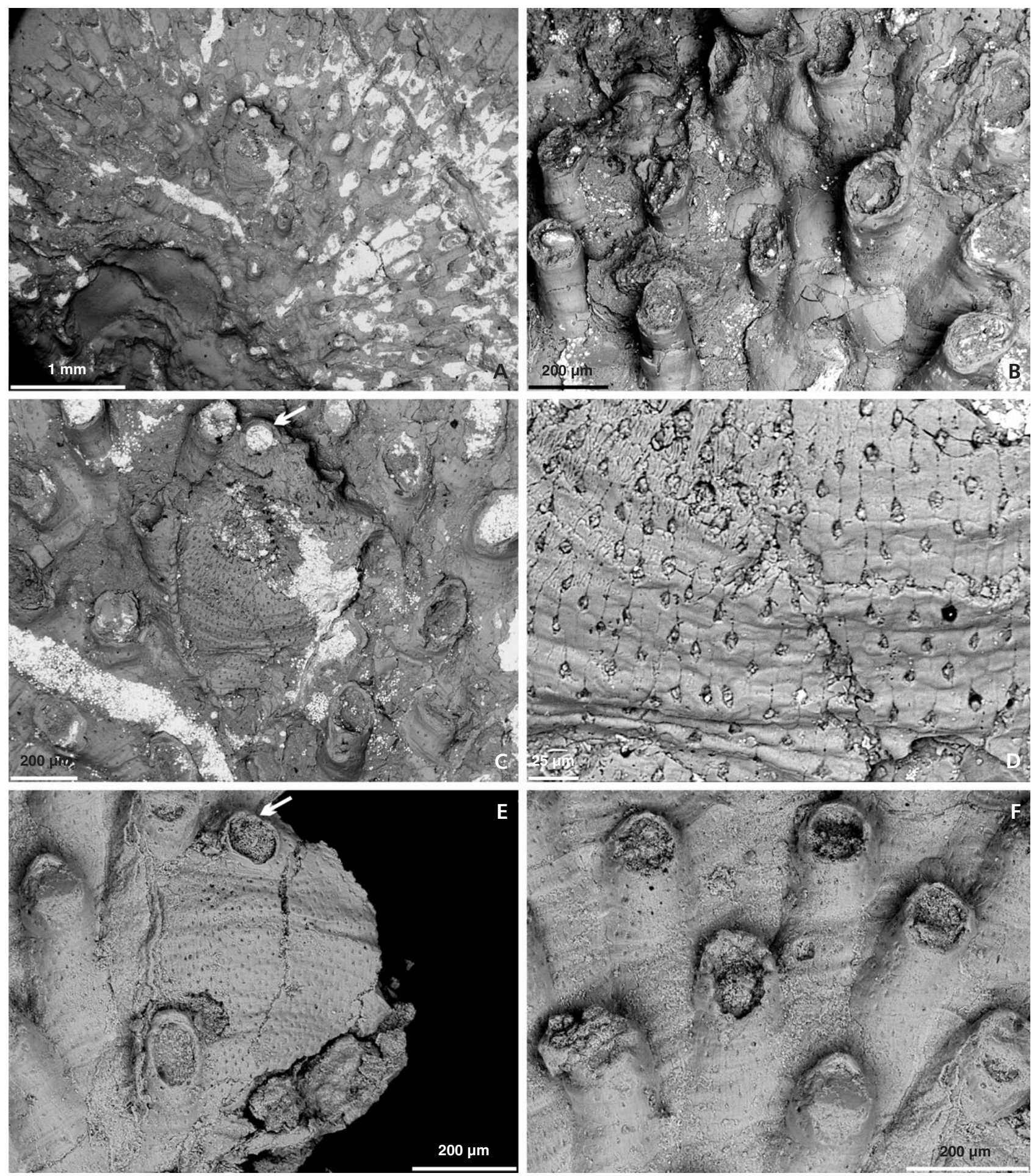

Figure 6. Microeciella aff. mokrskoensis Zatoń \& Taylor, 2009a, Lower Bathonian, Polish Jura. • A-D - Kawodrza Górna, GIUS 8-3561. $\bullet$ E, F-Ogrodzieniec, GIUS 8-3571. • A - colony. $\bullet$ B, F - autozooids. $\bullet$ C, E - gonozooids with subterminal ooeciopores (arrowed). $\bullet$ - pseudopores.

moderate length, proximal parts flat and distal convex; autozooid boundaries distinct. Preserved peristomes short, tapering distally, some upright. Autozooid apertures semicircular to longitudinally elongated, some closed by terminal diaphragms (Fig. 7C, E). Pseudopores apparently teardrop-shaped, pointed distally (Fig. 7D, F). Gonozooid proximal part undistinguishable from an autozooid frontal wall. Brood chamber inflated, ovoidal, 

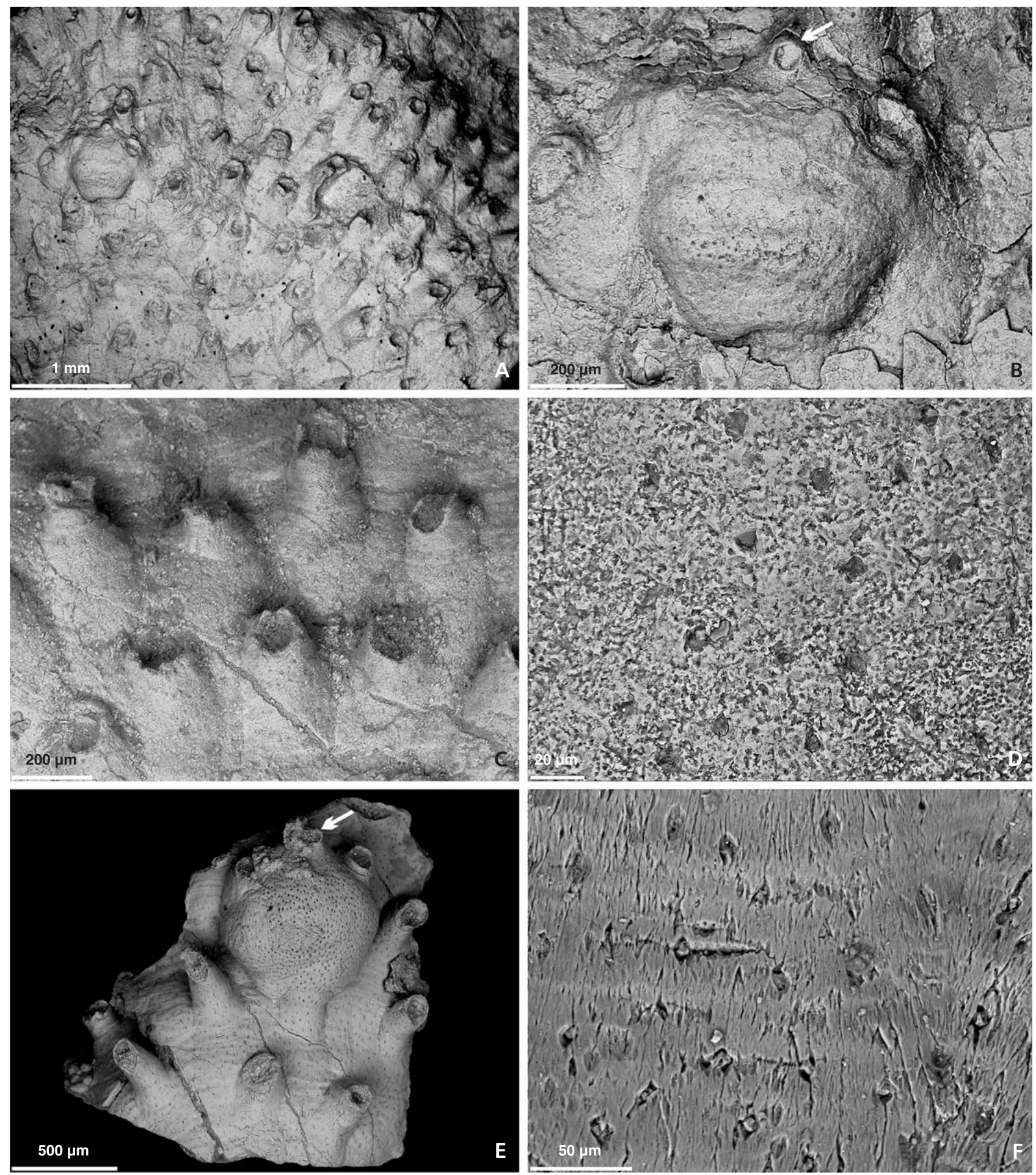

Figure 7. Microeciella aff. maleckii Zatoń \& Taylor, 2009a, Lower Bathonian, Ogrodzieniec, Polish Jura. A-D - GIUS 8-3572/1, E, F - GIUS 8-3572/2. $\bullet$ A - colony. $\bullet$ B - gonozooid with subterminal ooeciopore (arrowed). $\bullet \mathrm{C}$ - autozooids. $\bullet \mathrm{D}, \mathrm{F}-$ pseudopores. $\bullet \mathrm{E}$ - colony fragment showing autozooids and gonozooid with subterminal ooeciopore (arrowed).

slightly longer than wide, with densely pseudoporous roof. Ooeciopore small, subterminal, nearly circular, closed by subterminal diaphragm, located on a short ooeciostome (Fig.7B, E).
Discussion. - The two colonies described above differ slightly from each other with respect to some quantitative features, for example the brood chamber is larger in specimen GIUS 8-3572/2 (Fig. 7E). Autozooid width is similar 

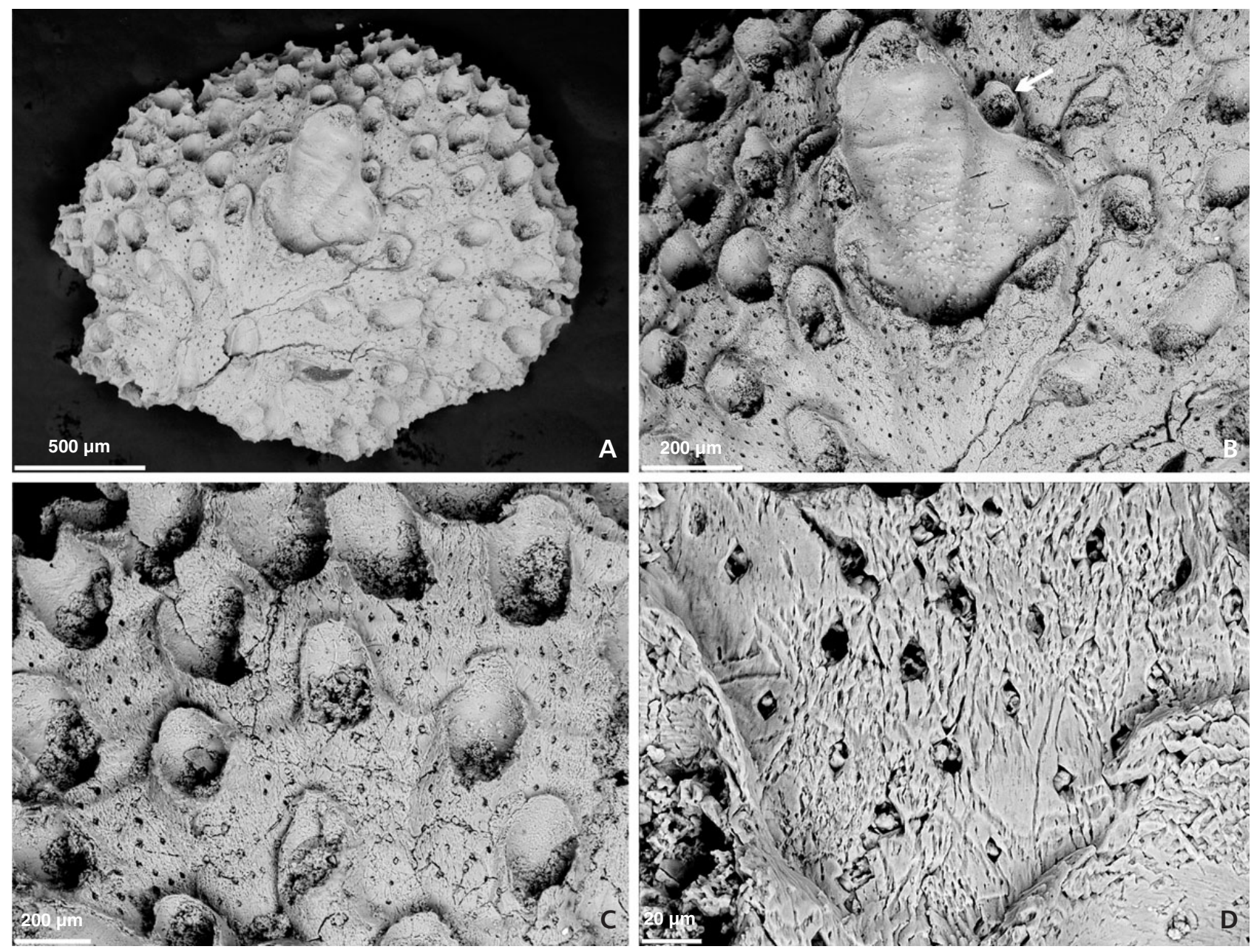

Figure 8. Microeciella sp., Lower Bathonian, Ogrodzieniec, Polish Jura, GIUS 8-3573. • A - colony fragment view. • B - gonozooid. The arrow points to autozooidal aperture only reminding an ooeciopore. $\bullet \mathrm{C}$ - autozooids. $\bullet \mathrm{D}-$ pseudopores.

in the two colonies, as is the ovoidal brood chamber shape with a subterminally located ooeciopore. Pseudopores also have similar shapes, appearing longer in specimen GIUS 8-3572/2 as a result only of their worn preservation (Fig. 7F). The colonies are regarded as being most closely related to the Upper Bathonian species M. maleckii, described from hiatus concretions in the Polish Jura (Zatoń \& Taylor 2009a). Especially similar are the ovoidal brood chambers with subterminal ooeciopores. A difference is evident in autozooid width which is in the new material.

It is interesting to note that brood chamber sizes of both colonies fall within the range of sizes of brood chambers present in a single colony of $M$. maleckii described by Zatoń \& Taylor (2009a). This exemplifies well the problem of intraspecific variability in these taxonomically important features of cyclostome bryozoans.

Occurrence. - Lower Bathonian of Ogrodzieniec, Polish Jura.

\section{Microeciella sp.}

Figure 8

Material. - One fertile colony fragment originally encrusting an oncolith.

Measurements. - Transverse apertural diameter $=88-99 \mu \mathrm{m}$; longitudinal aperture diameter $=77-121 \mu \mathrm{m}$; frontal wall length $=395-435 \mu \mathrm{m}$; frontal wall width $=132-143 \mu \mathrm{m}$; gonozooid total length $=934 \mu \mathrm{m}$; gonozooid brood chamber length $=637 \mu \mathrm{m}$; gonozooid width $=538 \mu \mathrm{m}$; ooeciopore diameter $=77 \mu \mathrm{m}$; pseudopore length $=17.5 \mu \mathrm{m}$; pseudopore width $=6.5 \mu \mathrm{m}$.

Description. - Colony encrusting, sheet-like, bereniciform, multiserial, unilamellar (Fig. 8A). Autozooids short, with flat frontal walls; autozooid boundaries indistinct. Preserved peristomes short with semicircular to longitudinally elongated apertures, quite densely arranged on the colony surface (Fig. 8C). Frontal wall worn but pseudopores apparently 
originally spindle-shaped (Fig. 8D). Proximal part of gonozooid indistinguishable from an autozooid frontal wall. Brood chamber roof not preserved, originally inflated, ovoidal with left margin distinctly elongated. Ooeciopore not preserved, probably terminal judging from tapering shape of worn brood chamber (Fig. 8B).

Discussion. - The shape of the brood chamber is reminiscent of M. maleckii Zaton \& Taylor, the holotype of which possesses a brood chamber characterised by undulating margins (see Zatoń \& Taylor 2009a, fig 5A, B). The latter species, however, has a subterminal ooeciopore, its autozooids are twice as long, have convex frontal walls and distinct zooidal boundaries marked by shallow grooves. Additional fertile and better preserved colonies are needed before a new species can be established.

Occurrence - Lower Bathonian of Ogrodzieniec, Polish Jura.

Family Multisparsidae Bassler, 1935

\section{Genus Reptomultisparsa d'Orbigny, 1853}

Type species. - Diastopora incrustans d'Orbigny, 1850; Middle Jurassic, Bathonian, Normandy, France.

\section{Reptomultisparsa kawodrzanensis sp. nov.}

\section{Figure 9}

Types. - Holotype (GIUS 8-3563/1), paratypes (GIUS 8-3563/2-5).

Type locality. - Kawodrza Górna, Polish Jura, Poland.

Type horizon. - Ore-Bearing Częstochowa Clay Formation, lowermost Bathonian, Zigzag Zone, Convergens Subzone, Middle Jurassic.

Etymology. - From the locality of Kawodrza.

Material. - Apart from the holotype and four paratypes listed above, which are all fertile colonies, there are an additional 16 colonies, of which two are fertile and most of the rest represent early growth stages. A single fertile colony from the Middle Jurassic of Gnaszyn Dolny is also tentatively assigned to the new species.
Measurements. - Transverse apertural diameter $=69$ to $141 \mu \mathrm{m}$; longitudinal aperture diameter $=111-156 \mu \mathrm{m}$; frontal wall length $=542-984 \mu \mathrm{m}$; frontal wall width $=$ 139-203 $\mu \mathrm{m}$; gonozooid total length $=1097-2344 \mu \mathrm{m}$; gonozooid brood chamber length $=944-1719 \mu \mathrm{m}$; gonozooid width $=367-500 \mu \mathrm{m}$; ooeciopore length = 76-91.4 $\mu \mathrm{m}$; ooeciopore width $=90-114 \mu \mathrm{m}$; pseudopore length $=7$ to $12 \mu \mathrm{m}$; pseudopore width $=6-8.2 \mu \mathrm{m}$.

Diagnosis. - Reptomultisparsa with elongate ovoidal to cylindrical brood chambers, 2-3 times longer than wide, ooeciopore subcircular to slightly elliptical and smaller than an autozooid aperture; pseudopores wide, teardrop-shaped.

Description. - Colony encrusting, sheet-like, multiserial, unilamellar, bereniciform. In early astogeny the colony is fan-shaped, becoming discoidal later (Fig. 9A). Ancestrula with large protoecium, about 179-196 $\mu \mathrm{m}$ in diameter, apparently pseudoporous over entire surface; distal tube short, about $82 \mu \mathrm{m}$ long, straight; aperture about $50 \mu \mathrm{m}$ in diameter; one distal autozooid budded from ancestrula (Fig. 9B).

Autozooids elongate, with slightly convex frontal walls; zooidal boundaries well-marked as shallow grooves. Peristomes short, tapering distally. Apertures circular to longitudinally elongated (Fig. 9D, F, G). Pseudopores wide, teardrop-shaped, pointed distally, widely spaced (Fig. 9H).

Gonozooids common, with up to two per colony, generally crushed. Proximal frontal wall short in comparison to brood chamber, flat, indistinguishable from autozooid frontal walls. Brood chamber convex, longitudinally elongated, ovoidal (in some paratypes, Fig. 9G) to cylindrical (in holotype and other paratypes, Fig. 9C, D, F), 2-3 times longer than wide, with edges indented by neighbouring autozooids, roof densely pseudoporous. Ooeciopore subterminal, somewhat transversely elliptical, smaller than an autozooid aperture, located on a short ooeciostome (Fig. 9E-G).

Remarks. - This species is exceptionally common on oyster shells encrusting fossil wood from Kawodrza Górna. Although the neighbouring colonies do not possess gonozooids, they share the same skeletal features as the fertile colonies and thus they are considered to be conspecific and possibly represent the same spatfall. However, it is

Figure 9. Reptomultisparsa kawodrzanensis sp. nov., Lower Bathonian, Kawodrza Górna, Polish Jura. • C-E - holotype, GIUS 8-3563/1. - A, B, F-H - paratypes. A, B - GIUS 8-3563/2, F- GIUS 8-3562, G-H - GIUS 8-3563/3. • A - view of neighbouring colonies encrusting an oyster shell. Ancestrula visible in the lower right. $\bullet \mathrm{B}$ - enlarged view of ancestrula shown in A, with worn protoecium. $\bullet \mathrm{C}-\mathrm{two}$ crushed gonozooids, one with preserved ooeciopore (left). $\bullet$ D - enlarged brood chamber with autozooids. $\bullet$ E - subterminal ooeciopore on a short ooeciostome (arrowed). $\bullet$ F, G - partly crushed brood chambers with ooeciopores visible (arrowed). $\bullet \mathrm{H}-$ pseudopores. 

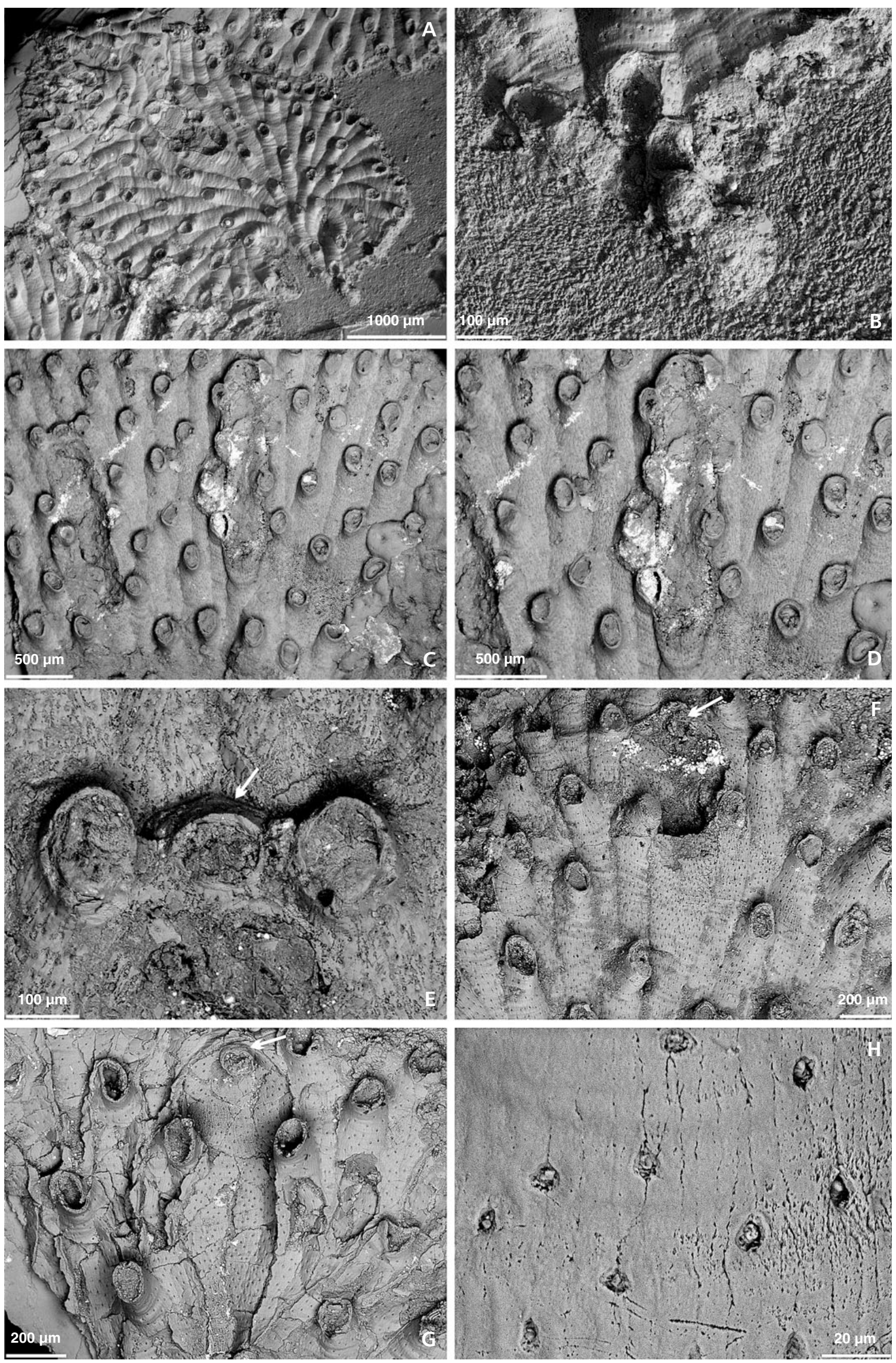

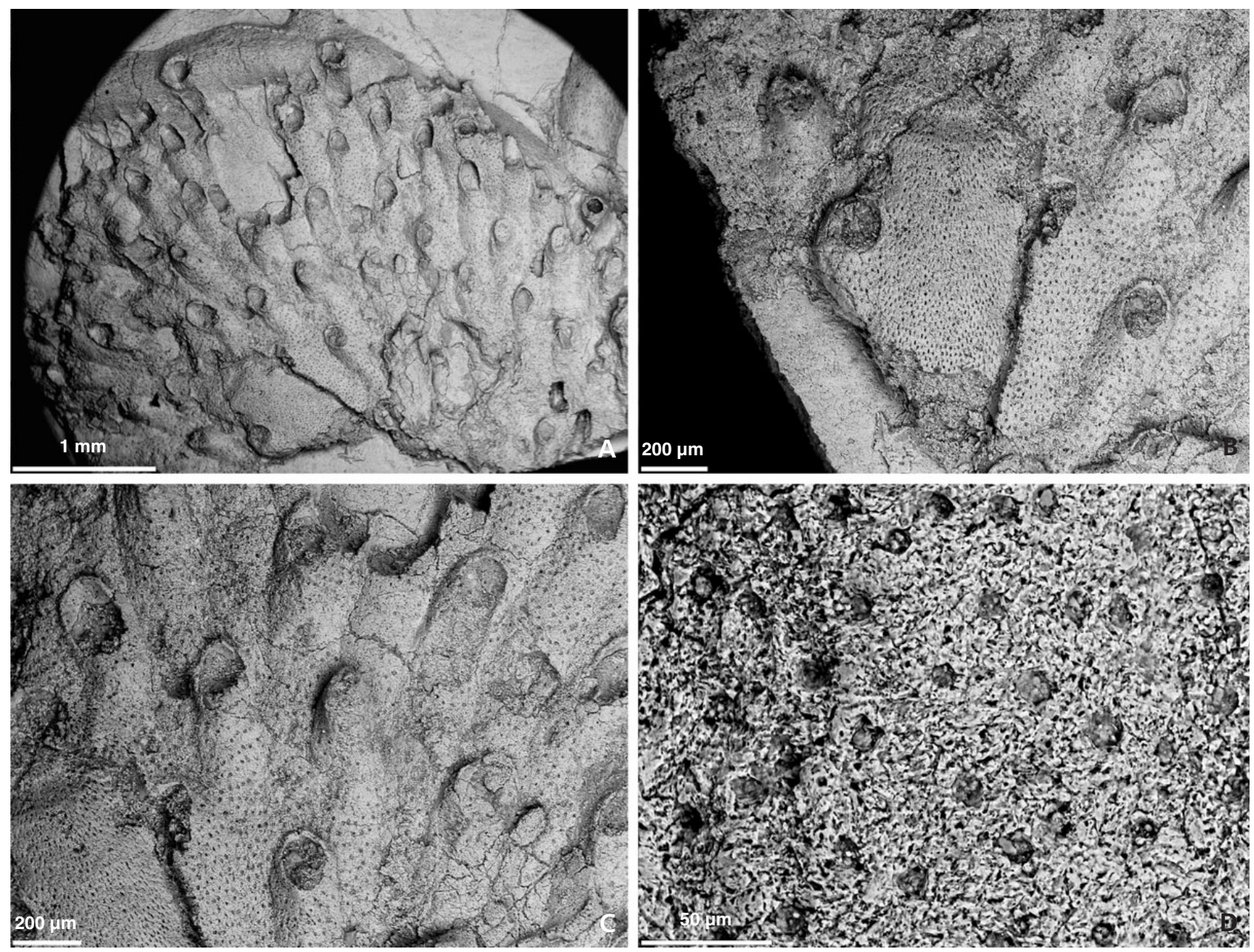

Figure 10. Reptomultisparsa sp., Lower Bathonian, Ogrodzieniec, Polish Jura, GIUS 8-3569/2. • A - colony overgrowing Stomatopora sp. at the top. $\bullet \mathrm{B}$ - gonozooid. $\bullet \mathrm{C}$ - autozooids. $\bullet \mathrm{D}$ - pseudopores in corroded frontal wall.

noticeable that the gonozooids of some adjacent colonies encrusting the same substrate may differ slightly, varying from forms with elongate, cylindrical brood chambers in the holotype, to shorter and wider brood chambers in the paratypes. Thus, it seems that, although the rest of the skeletal features are the same, the brood chambers show intraspecific variability as has been noticed in some other Jurassic (e.g. Hara \& Taylor 2009, Zatoń \& Taylor 2009a) and also Cretaceous (e.g. Hillmer 1968) cyclostome species.

The new species described here differs significantly from the recently described $R$. harae Zaton \& Taylor (2009a) from the Upper Bajocian of England and the Middle Bathonian of Poland. First, the brood chambers of $R$. kawodrzanensis sp. nov., although of similar length to those of $R$. harae, are distinctly narrower and have an ooeciopore of nearly half the size located on a short, upright ooeciostome. Autozooids of $R$. harae are of greater width and length (mean 242 and $1020 \mu$ m respectively) than those of $R$. kawodrzanensis sp. nov. (mean 183 and $144 \mu \mathrm{m}$, re- spectively). The pseudopores of $R$. harae are long and slitlike, while in $R$. kawodrzanensis sp. nov. they are shorter, wider and teardrop-shaped. The type species of Reptomultisparsa, $R$. incrustans (d'Orbigny, 1850), also differs in its ooeciopore which is larger than the autozooid apertures. $R$. saratovensis Viskova, 2009, described recently from the Lower Bathonian of Russia, has similar autozooids and elongated gonozooids. However, the gonozooids possess transverse ribs (see Viskova 2009) and pseudopore morphology is not evident, making closer comparison difficult.

One fertile colony (GIUS 8-3566) from the Middle Bathonian of Gnaszyn Dolny is very similar to the species described here with respect to gonozooid morphology as well as autozooid width. However, the frontal walls are heavily worn and thus pseudopore morphology is unclear. Some pseudopores that may have retained their original morphology are of smaller width than those of $R$. kawodrzanensis sp. nov., but are wider than those of $R$. harae. The colony is here assigned to the species $R$. kawodrzanensis, but with a question mark. 
Occurrence. - Lowermost Bathonian of Kawodrza Górna and questionably from the Middle Bathonian of Gnaszyn Dolny, Polish Jura.

\section{Reptomultisparsa sp.}

Figure 10

Material. - One fertile colony, originally encrusting an oncolith.

Measurements. - Transverse aperture diameter $=120 \mu \mathrm{m}$; longitudinal aperture diameter $=160-180 \mu \mathrm{m}$; frontal wall length $=851-980 \mu \mathrm{m}$; frontal wall width $=200-240 \mu \mathrm{m}$; preserved gonozooid brood chamber length $=1319 \mu \mathrm{m}$; gonozooid width $=528 \mu \mathrm{m}$; pseudopore length $=8.9-11 \mu \mathrm{m}$; pseudopore width $=7.8-12.2 \mu \mathrm{m}$.

Description. - Colony encrusting, sheet-like, bereniciform, multiserial, unilamellar, fragmentary mostly with poor surface preservation (Fig. 10A). Autozooids long, with flat to slightly convex frontal walls; autozooid boundaries distinct. Preserved peristomes short, tapering distally. Apertures longitudinally elongated, some closed by pseudoporous terminal diaphragms (Fig. 10C). Pseudopores densely spaced, semicircular (Fig. 10D).

Gonozooid lacking the proximal part. Brood chamber slightly inflated, elongate, pyriform in shape, with densely pseudoporous roof. Ooeciopore inconspicious (Fig. 10B).

Discussion. - Some characteristics, such as brood chamber shape and size and pseudopore morphology, are similar to those of Reptomultisparsa kawodrzanensis described above. The latter species, however, has autozooids somewhat smaller in width. Also the position and size of the ooeciopore in the colony described here is not clear due to the state of preservation. The size and shape of the gonozooid is also similar to R. harae, known from the Upper Bajocian and Middle Bathonian of England and Poland (see Zatoń \& Taylor 2009a), but the latter species has distinctly slit-like pseudopores. Autozooid and gonozooid sizes, as well as the pseudopores, are similar to $R$. cobra (Pitt \& Thomas, 1969) and $R$. aff. cobra described by Taylor (2009) and Zatoń \& Taylor (2009a) from the Middle Jurassic of Poland. However, R. cobra is characterised by its multilamellar colonies with flat autozooid and gonozooid frontal walls. Thus, the colony described here is more probably related to such species as $R$. kawodrzanensis sp. nov., although its state of preservation does not allow a more definite assignment.

Occurrence. - Lower Bathonian of Ogrodzieniec, Polish Jura.
Family Plagioeciidae Canu, 1918

Genus Hyporosopora Canu \& Bassler, 1929

Type species. - Hyporosopora typica Canu \& Bassler, 1929, Bathonian of Normandy, France.

\section{Hyporosopora bugajensis Zatoń \& Taylor, 2009a} Figure 11

2009a Hyporosopora bugajensis sp. nov. - Zatoń \& Taylor, p. 281, fig. 11.

Emended diagnosis. - Hyporosopora with small, transversely elliptical to triangular or heart-shaped brood chambers with distinct distal lobes.

Material. - Two fertile colonies encrusting oyster shells and one poorly preserved colony questionably assigned encrusting a bivalve shell.

Measurements. - Transverse apertural diameter $=81$ to $107 \mu \mathrm{m}$; transverse peristomial diameter $=100-140 \mu \mathrm{m}$; longitudinal aperture diameter $=100-153 \mu \mathrm{m}$; longitudinal peristomial diameter $=129-200 \mu \mathrm{m}$; frontal wall length $=$ 466-812 $\mu \mathrm{m}$; frontal wall width $=153-187.5 \mu \mathrm{m}$; gonozooid total length $=1064 \mu \mathrm{m}$; gonozooid brood chamber length $=448-634 \mu \mathrm{m}$; gonozooid width $=902-1029 \mu \mathrm{m}$; transverse ooeciopore width $=65-75.5 \mu \mathrm{m}$; ooeciopore length $=65-88 \mu \mathrm{m}$; pseudopore length $=1.2-2.5 \mu \mathrm{m}$; pseudopore width $=10.5-14 \mu \mathrm{m}$.

Discussion. - H. bugajensis was introduced by Zatoń \& Taylor (2009a). With respect to some skeletal features, the colonies under discussion resemble $H$. sauvagei (Gregory, 1896), originally described from the Upper Bathonian of England. As in the holotype of $H$. sauvagei, the Polish colonies are characterised by gull wingshaped pseudopores. However, their brood chambers are significantly smaller, and the autozooids are nearly twice as narrow as those of $H$. sauvagei. The smaller brood chambers (Fig. 11B, F, G), narrower autozooids (Fig. 11C, H) and unique, transversely elongated pseudopores (Fig. 11D) indicate that the colonies described here belong instead to the Middle Bathonian species H. bugajensis.

The holotype of $H$. bugajensis, the only fertile colony known of this species (see Zatoń \& Taylor 2009a), has a single transversely elliptical brood chamber. However, allowing for the intrinsic variability of brood chamber shapes both within a single colony and between different colonies of species of Hyporosopora (e.g., Zatoń \& Taylor 2009a, Hara \& Taylor 2009), it is considered that the colonies described here represent $H$. bugajensis. 
One colony (GIUS 8-3558) from the Lower Bathonian (Tenuiplicatus Zone) of Kawodrza Górna ('Leszczyński' clay-pit) possesses a poorly preserved brood chamber wide proximally. Moreover, although the frontal wall is heavily worn some of the pseudopores show a distinct gull wing shape. The state of preservation means that this colony can only be placed tentatively in $H$. bugajensis.

Occurrence. - Middle Bathonian of Gnaszyn Dolny and possibly uppermost Lower Bathonian of Kawodrza Górna ('Leszczyński' clay-pit), Polish Jura.

\section{Hyporosopora sp. 1}

Figure 12 A-E

Material. - Two fragmentary colonies originally encrusting oncoliths.

Measurements. - Transverse apertural diameter $=80 \mu \mathrm{m}$; frontal wall length $=298-384 \mu \mathrm{m}$; frontal wall width $=$ 105-115 $\mu \mathrm{m}$; gonozooid brood chamber length $=513$ to $586 \mu \mathrm{m}$; gonozooid width $=903-1013 \mu \mathrm{m}$; ooeciopore length $=53 \mu \mathrm{m}$; ooeciopore width $=73-77 \mu \mathrm{m}$; pseudopore length $=12 \mu \mathrm{m}$; pseudopore width $=7.2 \mu \mathrm{m}$.

Description. - Due to the delicate nature of these colonies encrusting oncoliths, only small parts could be retrieved for SEM study. Both colonies are sheet-like, multiserial and unilamellar (Fig. 12A, B). One colony fragment (Fig. 12A) consists of a brood chamber and a few neighbouring autozooids. Autozooid frontal walls are short and flat, with short, distally tapering peristomes, and apertures are nearly circular. Although the frontal wall surface is strongly worn, the pseudopores are teardrop-shaped. The brood chamber is small, inflated, and broadly elliptical, with a width twice the length. Its lateral margins are indented by two autozooid apertures. The ooeciopore is terminal, slightly smaller than an autozooid aperture, nearly circular in outline, and slightly wider than long. The ooeciostome is short and upright.

The second colony fragment (Fig. 12B-E) has a single gonozooid. Autozooid frontal walls are similar to those of the first colony but some of the apertures are closed by diaphragms (Fig. 12D). Pseudopores are teardrop-shaped, pointed distally (Fig. 12E). The brood chamber is transversely elongated, elliptical in outline; its roof is densely pseudoporous but crushed and encrusted probably by a brachiopod (Fig. 12C). Nevertheless, its width and length are quite similar to the brood chamber of the first colony. The poorly preserved ooeciopore is terminal.

Remarks. - Because of the similarities in the morphology of the autozooid frontal wall, aperture shape and size, and pseudopores, these two fragmentary colonies are here regarded as conspecific. Even the brood chambers, although varying slightly in outline and size, are similar in being elliptical and having terminal ooeciopores. With respect to brood chamber shape, the colonies described here are most similar to the holotype of the Middle Bathonian species Hyporosopora bugajensis Zaton \& Taylor, 2009a. The latter species, however, possesses much longer and wider autozooid frontal walls and transversely elongated, narrow, gull wing-shaped pseudopores.

Occurrence. - Lower Bathonian of Ogrodzieniec, Polish Jura.

\section{Hyporosopora sp. 2}

Figure $12 \mathrm{~F}-\mathrm{H}$

Material. - A single colony originally encrusting an oncolith.

Measurements. - Transverse apertural diameter $=122$ to $148 \mu \mathrm{m}$; longitudinal aperture diameter $=135-180 \mu \mathrm{m}$; frontal wall length $=580-903 \mu \mathrm{m}$; frontal wall width $=$ 193-219 $\mu \mathrm{m}$; preserved gonozooid brood chamber length $=$ $1220 \mu \mathrm{m}$; gonozooid width $=770 \mu \mathrm{m}$; pseudopore length $=$ $8.6 \mu \mathrm{m}$; pseudopore width $=7.7-8.6 \mu \mathrm{m}$.

Description. - Colony encrusting, multiserial, sheet-like and unilamellar; surface encrusted by two large serpulids, one covering left part of the brood chamber (Fig. 12F). Autozooid frontal walls vary in length, but their width is more uniform. Apertures semicircular to longitudinally elongated (Fig. 12G). Pseudopores small, circular in outline (Fig. 12H).

Total length of gonozooid unknown. Brood chamber probably triangular, heart-shaped, inflated, with densely pseudoporous roof and right margin indented by closely spaced neighbouring autozooids, six in number (Fig. 12F). Ooeciopore not identified.

Remarks. - The general outline of the preserved right part of the brood chamber, which takes the form of a distinct distal lobe from a heart-shaped structure, suggests that the colony described here belongs to Hyporosopora. Brood

Figure 11. Hyporosopora bugajensis Zatoń \& Taylor, 2009a, Middle Bathonian, Gnaszyn Dolny, Polish Jura. • A-D - GIUS 8-3567/1, E-H - GIUS 8-3567/2. • A, E - colony. $・$ B, F, G - gonozooids with terminal ooeciopores (arrowed). $\bullet$ C, H - autozooids. $\bullet$ D - pseudopores. 

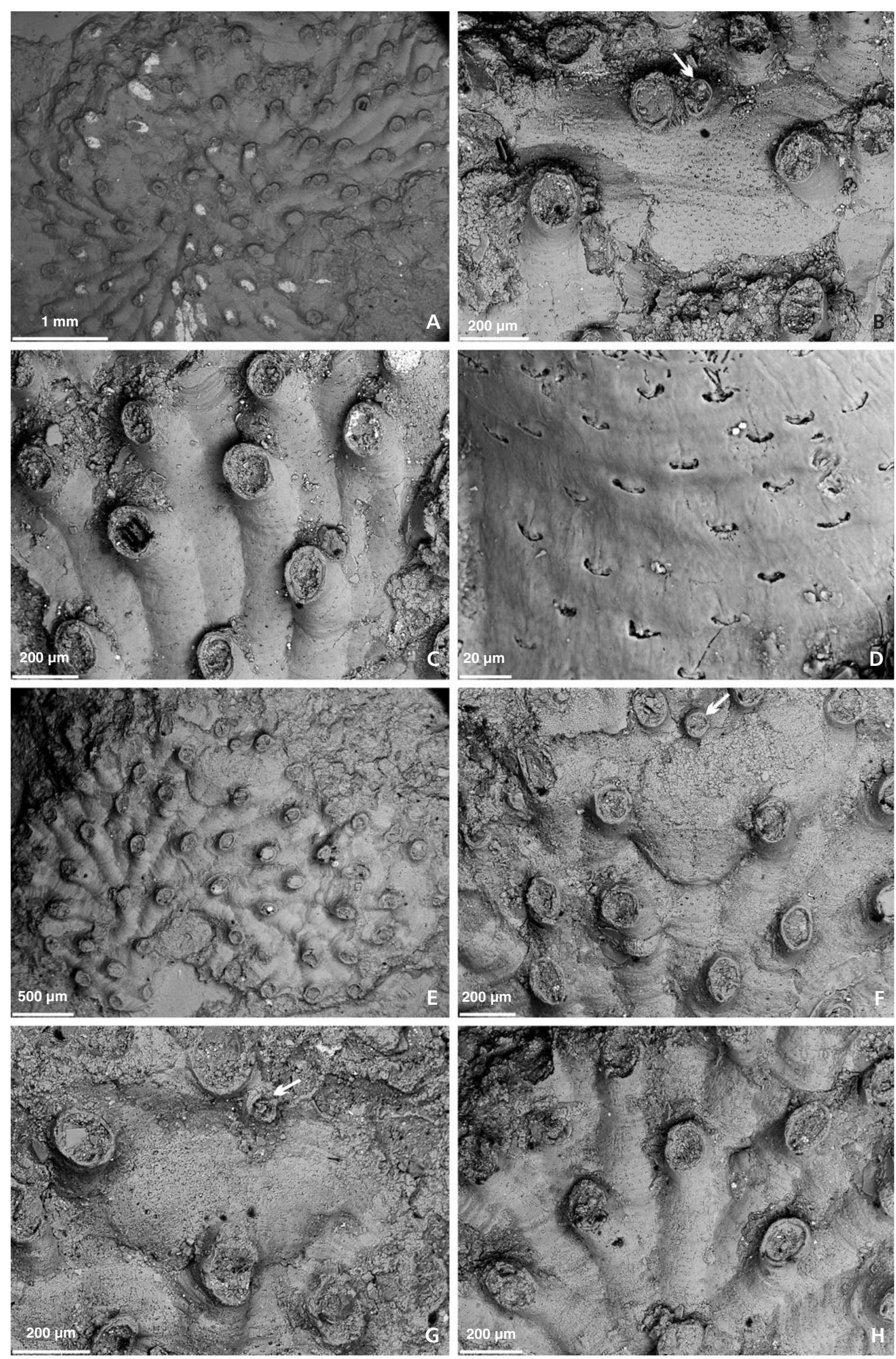
chamber shape is reminiscent of $H$. tenera (Reuss, 1867), described from the Middle Bathonian of the Polish Jura (Zatoń \& Taylor 2009a) and Upper Bathonian or Lower Callovian of Balin (Taylor 2009). However, several skeletal features distinguish the latter species from the colony described here. In H. tenera the brood chamber is more triangular in shape, with a nearly flat distal margin. Furthermore, autozooids of $H$. tenera are smaller and the pseudopores are longitudinally elongated and slit-like.

Occurrence. - Lower Bathonian of Ogrodzieniec, Polish Jura.

\section{Hyporosopora sp. 3}

Figure 13

Material. - One fertile colony encrusting an oyster shell.

Measurements. - Transverse apertural diameter $=78$ to $106 \mu \mathrm{m}$; transverse peristomial diameter $=107-125 \mu \mathrm{m}$; longitudinal aperture diameter $=113-173 \mu \mathrm{m}$; longitudinal peristomial diameter $=131-201 \mu \mathrm{m}$; frontal wall length $=$ 574-756 $\mu \mathrm{m}$; frontal wall width $=139-179 \mu \mathrm{m}$; gonozooid total length $=1057-1174 \mu \mathrm{m}$; gonozooid brood chamber length $=673-678 \mu \mathrm{m} ;$ gonozooid width $=1104-1182 \mu \mathrm{m}$; transverse ooeciopore width $=87 \mu \mathrm{m}$; ooeciopore length $=$ $70 \mu \mathrm{m}$; pseudopore length $=5.8-7.5 \mu \mathrm{m}$; pseudopore width $=5.8-8.3 \mu \mathrm{m}$.

Description. - Colony encrusting, sheet-like, bereniciform, discoidal in outline, multiserial, unilamellar (Fig. 13A). Autozooids of moderate length and small width, elongate with convex frontal wall; zooidal boundaries distinct, marked by shallow grooves. Preserved peristomes taper distally. Apertures semicircular to longitudinally elongated (Fig. 13E). Pseudopores moderately dense, semicircular (Fig. 13F).

Two gonozooids are present but both are crushed. Proximal part indistinguishable from an autozooid (Fig. 13B, D). Brood chamber much broader than long, boomerang-like with prominent distal lobes. Ooeciopore terminal, semicircular, smaller than an autozooid aperture. Ooeciostome short, upright (Fig. 13C, D).

Remarks. - This is a problematic species. Despite the presence of gonozooids, it is not easy to assign it to a species. The boomerang-like brood chambers with prominent distal lobes are reminiscent of $H$. sauvagei (Gregory, 1896) and allied species such as $H$. aff. sauvagei described by Taylor (2009) and Zatoń \& Taylor (2009a) from the Middle Jurassic of Poland. In the latter species, however, they are much broader. Other features, such as autozooid width, are significantly greater in the latter species. The new colonies of $H$. bugajensis described above possess autozooids and brood chambers of quite similar size; however, the brood chambers of the latter are slightly smaller and lack such prominent distal lobes. Pseudopores are also completely different in $H$. bugajensis, being transversely elongate and gull wing-shaped, in contrast to the semicircular pseudopores in the colony described here.

With respect to autozooid size and pseudopore morphology, the colony described is similar to an unnamed species of Hyporosopora recently described by Zaton \& Taylor (2009a) from the Upper Bathonian of the Polish Jura. The latter species, however, possesses only one, incomplete brood chamber that does not allow for closer comparison. However, were this brood chamber to be complete, it would probably not be as large as those preserved in the present colony. Summing up, the colony described in the present paper possesses a mix of features present in other Hyporosopora species, and thus its specific assignment is difficult.

Occurrence. - Middle Bathonian of Gnaszyn Dolny, Polish Jura.

Family Entalophoridae Reuss, 1869

\section{Genus Mecynoecia Canu, 1918}

Type species. - Entalophora proboscidea Milne-Edwards, 1838; Recent, Mediterranean; by original designation.

\section{Mecynoecia kaimi sp. nov.}

Figure 14

Types. - Holotype (ZPAL Br 13/8) and paratypes (ZPAL Br 13/2, 3, Br 13/6).

Type locality. - Krzyworzeka, Polish Jura, Poland.

Type horizon. - Ore-Bearing Częstochowa Clay Formation, Upper Bathonian, Hodsoni or Orbis Zone, Middle Jurassic.

Etymology. - In honour of our friend Dr Andrzej Kaim from the Institute of Paleobiology (Polish Academy of

Figure 12. Hyporosopora spp., Lower Bathonian, Ogrodzieniec, Polish Jura. • A-E - Hyporosopora sp. 1, GIUS 8-3574/1. • F-H - Hyporosopora sp. 2, GIUS 8-3574/2. $\bullet$ A, C, F- gonozooids, some with terminal ooeciopores (arrowed). B - colony fragment. $\bullet$ D, G - autozooids. $\bullet$ E, H - pseudopores. 

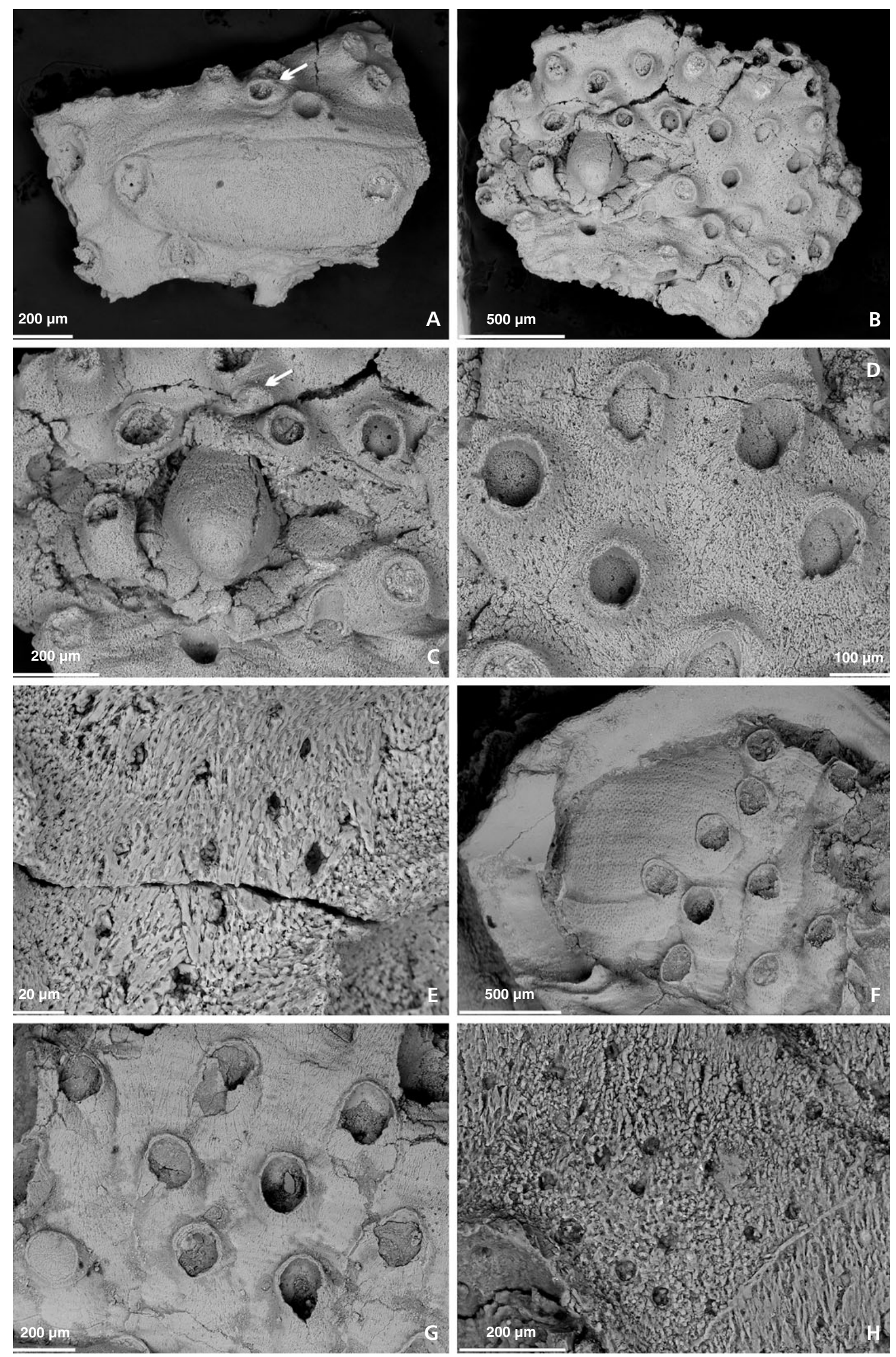

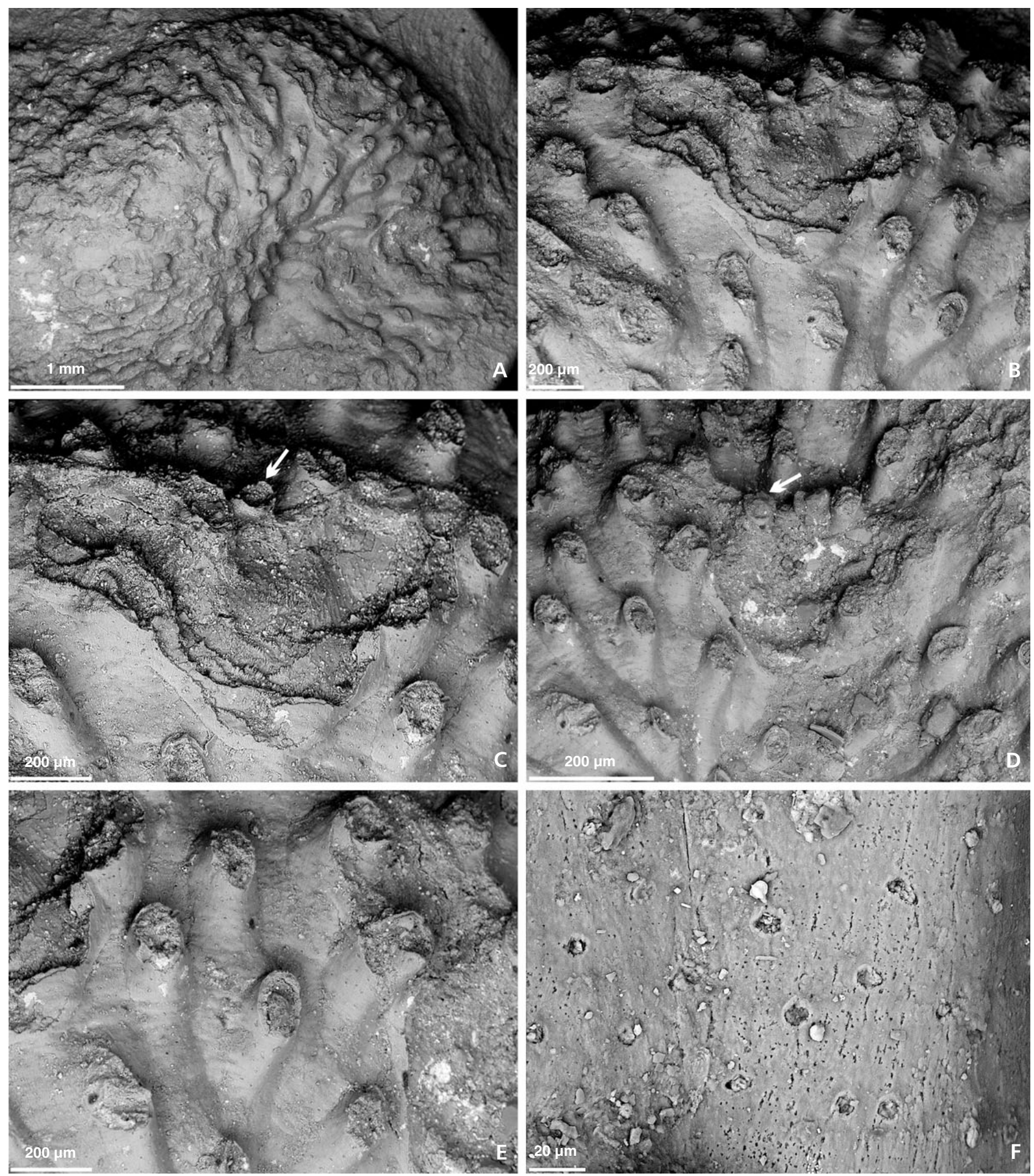

Figure 13. Hyporosopora sp. 3, Middle Bathonian, Gnaszyn Dolny, Polish Jura. GIUS 8-3564/1. • A - colony. • B-D - gonozooids with terminal ooeciopores (arrowed). $\bullet \mathrm{E}-$ autozooids. $\bullet \mathrm{F}-$ pseudopores.

Figure 14. Mecynoecia kaimi sp. nov., Upper Bathonian, Krzyworzeka, Polish Jura. $・$ A-C - holotype, ZPAL Br 13/8. • D-F- paratypes. D - ZPAL Br 13/2, E, F - ZPAL $13 \mathrm{Br}$ 13/3. • A - fertile branch fragment. • B - gonozooid. $\bullet \mathrm{C}$ - narrow ooeciopore (arrowed) adnate to an autozooid peristome. $\cdot \mathrm{D}$ - autozooids. $\bullet \mathrm{E}$ - paratype branch. $\bullet \mathrm{F}$ - pseudopores. 

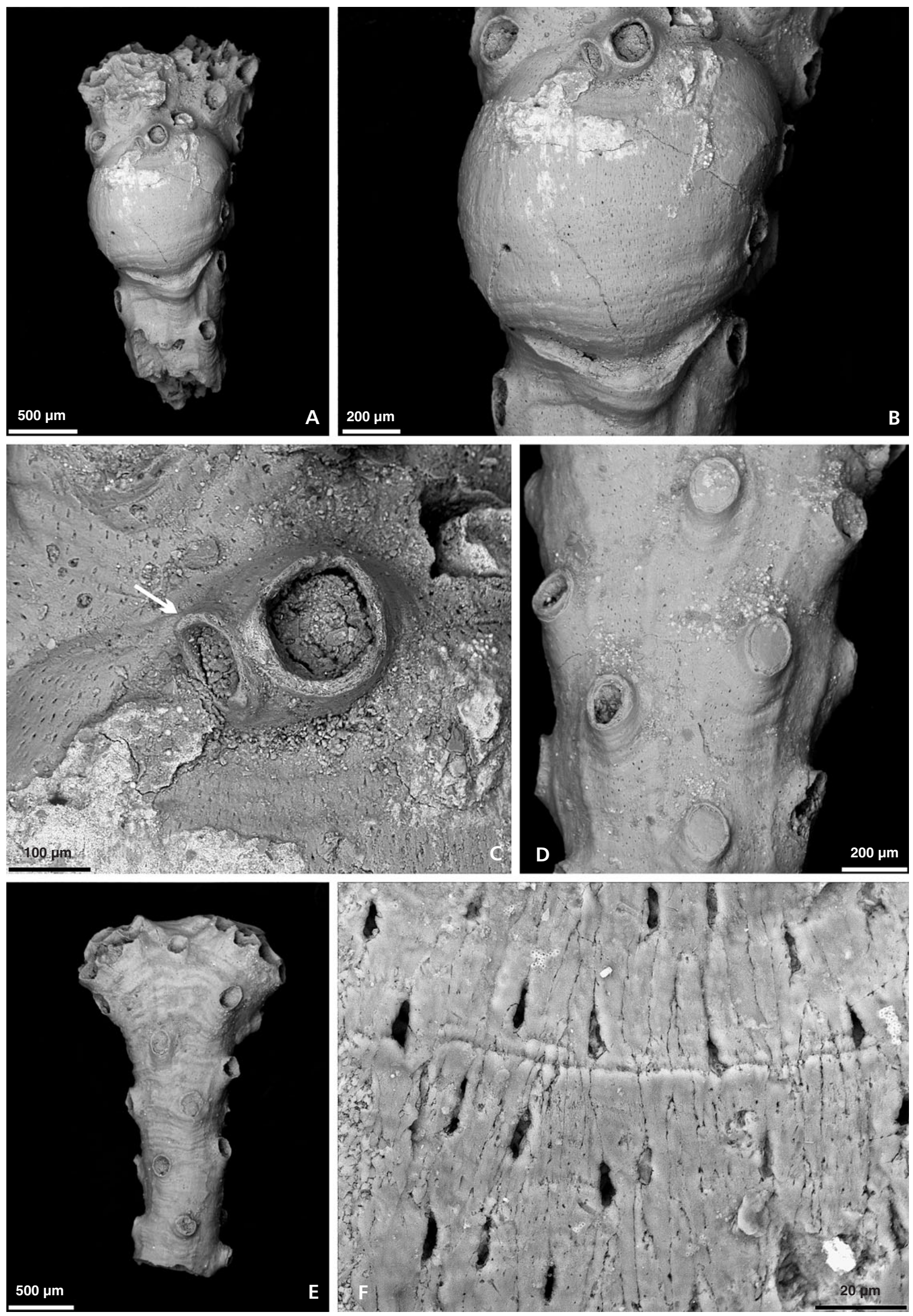
Sciences) in Warsaw, who found the specimens and provided them for study.

Material. - Apart from the holotype and paratypes listed above, there are numerous branch fragments.

Measurements. - Transverse apertural diameter $=78$ to $134 \mu \mathrm{m}$; longitudinal aperture diameter $=133-244 \mu \mathrm{m}$; frontal wall length $=705-1323 \mu \mathrm{m}$; frontal wall width $=$ 104-223 $\mu \mathrm{m}$; gonozooid total length $=1797 \mu \mathrm{m}$; gonozooid brood chamber length $=1304 \mu \mathrm{m}$; gonozooid width $=$ $1058 \mu \mathrm{m}$; ooeciopore length $=102 \mu \mathrm{m}$; ooeciopore width $=$ $51 \mu \mathrm{m}$; pseudopore length $=10-14.6 \mu \mathrm{m}$; pseudopore width $=1.7-3.9 \mu \mathrm{m}$.

Diagnosis. - Mecynoecia with flat autozooids; brood chamber globular, inflated with terminal, narrow and elliptical ooeciostome adnate to an autozooid peristome; pseudopores dense, slit-like.

Description. - Colonies erect, branches cylindrical (vinculariiform), narrow proximally and widening distally (Fig.14A, E) towards dichotomous bifurcations and reaching $1178 \mu \mathrm{m}$ in width.

Autozooids opening around entire branch circumference. Frontal walls elongate, flat proximally and slightly convex distally; transversely wrinkled. Boundary walls salient. Peristomes short. Apertures subcircular to slightly longitudinally elongate, some closed by terminal diaphragms (Fig. 14D). Pseudopores dense, slit-like, much longer than wide (Fig. 14F).

Gonozooid present only in one branch fragment; brood chamber globular, well-inflated, slightly longer than wide, its lateral margins indented by up to two neighbouring autozooids, and its distal margin indented by one autozooid (Fig. 14B). Roof densely pseudoporous. Ooeciopore located terminally, adnate to an autozooid peristome, oblique to axis of the zooid. Ooeciopore elliptical, narrow, longer than wide (nearly slit-like), situated on short ooeciostome smaller than an autozooid aperture (Fig. 14C).

Remarks. - This new species of Mecynoecia differs from the Upper Bajocian species M. bajocina (d'Orbigny, 1850) from Normandy and England (see Walter 1967) in its more elongate brood chamber and narrower ooeciopore. Brood chamber shape more closely resembles that of the Upper Jurassic (Oxfordian) M. suprabajocina Hara \& Taylor, 1996 from Bałtów, central Poland. However, the ooeciopore of the new species is distinctly elliptical and narrower. Moreover, M. kaimi differs from both M. bajocina and M. suprabajocina in having long, slit-shaped pseudopores that contrast with the subcircular pseudopores of the latter two species.
Although only one branch fragment has a gonozooid preserved, the other fragments from the same sample are considered conspecific on the basis of SEM observations of branch, autozooid and pseudopore characteristics.

Occurrence. - Upper Bathonian of Krzyworzeka, Polish Jura.

Entalophoridae gen. et. sp. indet.

Figure 15

Material. - Numerous infertile branch fragments.

Remarks. - Within the material consisting of branch fragments, two different species are evident from autozooid and pseudopore characteristics: Entalophoridae gen. et sp. indet. 1 (Fig. 15A-D) and Entalophoridae gen. et sp. indet. 2 (Fig. 15E-H). The lack of gonozooids makes generic assignment impossible, although the universal absence of a central lumen along the branch axis means they do not belong to the genus Entalophora (see Walter 1970, Taylor \& McKinney 2006, p. 22).

Occurrence. - Upper Bathonian of Krzyworzeka, Polish Jura.

Suborder Cerioporina Hagenow, 1851

Family Cavidae d'Orbigny, 1854

\section{Genus Ceriocava d'Orbigny, 1854}

Type species. - Millepora corymbosa Lamouroux, 1821, Bathonian, Normandy, France.

\section{Ceriocava sp.}

Figure 16

Material. - More than 17 specimens were found originally encrusting oncoliths.

Measurements. - Cone-like colonies: Aperture diameter: 110-195 $\mu \mathrm{m}$; interzooidal wall thickness: 37-86 $\mu \mathrm{m}$. Mixed free-/fixed-walled colonies: aperture diameter: 113-160 $\mu \mathrm{m}$; gonozooid total length: $1273 \mu \mathrm{m}$; gonozooid width: $406 \mu \mathrm{m}$; ooeciopore diameter: $264 \mu \mathrm{m}$; pseudopore length: 17-20 $\mu \mathrm{m}$; pseudopore width: $20-21 \mu \mathrm{m}$.

Description. - Colonies are encrusting, dome- to coneshaped with free-walled autozooids opening over entire upper surface (Fig. 16A, B), or sheet-like, multilamellar, possessing both the fixed- and free-walled autozooids (Fig. 16C). In the cone-shaped colonies, autozooid 

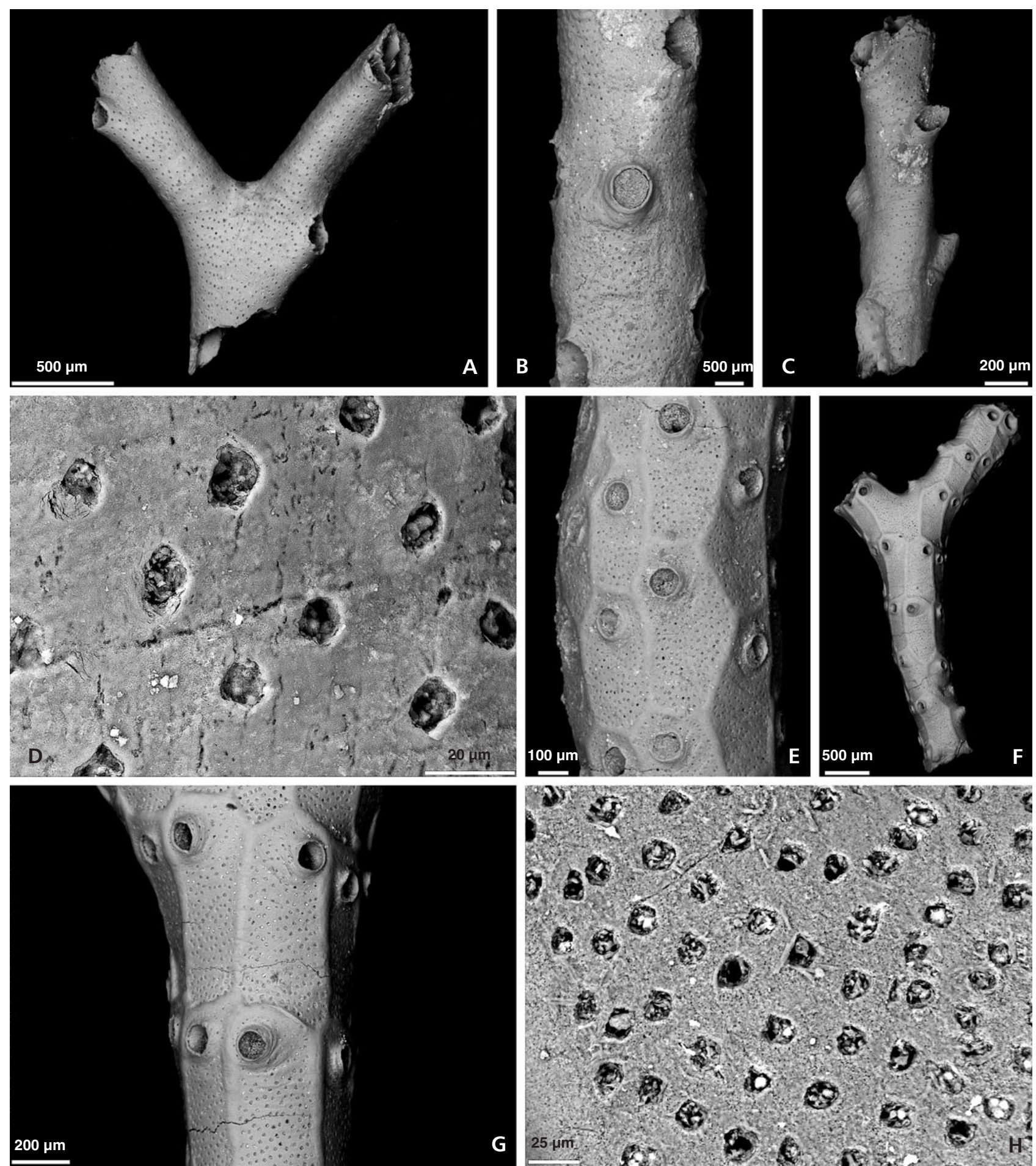

Figure 15. Undetermined entalophorid cyclostome bryozoans, Upper Bathonian, Krzyworzeka, Polish Jura. • A-D - Entalophoridae gen. et sp. indet. 1. A - ZPAL Br 13/17, B - ZPAL Br 13/14, C, D - ZPAL Br 13/15. • E-H - Entalophoridae gen. et sp. indet. 2. E - ZPAL Br 13/7, F-H - ZPAL Br 13/5. - A-C, E-G - branch fragments with autozooids visible. $\bullet \mathrm{D}, \mathrm{H}-$ pseudopores.

apertures are rounded polygonal and separated by raised, thick interzooidal walls, giving a honeycomb appearance. Autozooids in the fixed-walled parts of some colonies are small, up to $113 \mu \mathrm{m}$ in length and $160 \mu \mathrm{m}$ in width. Peri- stomes are short and upright with semicircular apertures, 113 to $160 \mu \mathrm{m}$ in diameter (Fig. 16C). Often they are closed by terminal diaphragms, some pseudoporous. Pseudopores on the frontal walls of fixed-walled autozooids 
are densely spaced, teardrop-shaped with a broad base (Fig. 16D).

Gonozooids are narrow and elongate, with densely pseudoporous roofs. The ooeciopore is terminal, subcircular, larger than an autozooid aperture, and can be closed by a terminal diaphragm with sparse pseudopores. The ooeciostome is short and upright (Fig. 16C).

Remarks. - The genus Ceriocava exhibits a wide array of colony morphotypes (see Walter 1970, Taylor 2009). Ceriocava colonies attached to the oncoliths studied here are represented mainly by cone- to dome-shaped morphotypes, but so-called 'flabellotrypiform' colonies may also be present. Similar colony forms of Ceriocava are present in Upper Bajocian and Bathonian hiatus concretions from the Polish Jura (Zatoń \& Taylor 2009a). It is unclear whether they all represent a single well-known species, C. corymbosa (Lamouroux, 1821), or several different species, pending detailed comparative investigations based both on external and internal skeletal features.

Occurrence. - Lower Bathonian of Ogrodzieniec, Polish Jura.

\section{Discussion}

Our knowledge of Jurassic bryozoan diversity is still incomplete (Taylor \& Ernst 2008). This is due to various factors, but two are most important: 1. Size and occurrence: most Jurassic bryozoans have tiny colonies that are patchily distributed on firm to hard substrates that may be irregularly distributed through stratigraphical sequences, making them easily overlooked by collectors; 2 . Taxonomy: Jurassic bryozoans consist overwhelmingly of cyclostomes whose taxonomy relies on rather few skeletal features. Genus-level taxonomy depends on brooding polymorphs (gonozooids). Unfortunately, in Jurassic cyclostomes gonozooids are present in a minority of colonies, even though colonies may be 'large' (see McKinney \& Taylor 1997).

Combining the data of Zaton \& Taylor (2009a) with that of the present paper, at least 29 species of cyclostomes appear to have inhabited the Polish Jura sector of the Polish Basin during the Bathonian. However, this value is an underestimate because the majority of colonies studied by us were infertile and thus indeterminate. Nevertheless, this species richness is high when compared with other Jurassic assemblages. The richest Jurassic bryozoan assemblage is from the Bathonian of Normandy, where 33 species of bryozoans have been recorded associated with oncoliths, shelly substrates, sponge bioherms and hardgrounds (see Walter 1970, Palmer \& Fürsich 1981, Taylor \& Ernst
2008). Certainly, facies played a significant role in bryozoan distribution and diversity in the Jurassic, as clay sediments contain assemblages much poorer in species than carbonates (see Taylor \& Ernst 2008). The Bathonian diversity peak seems to be real, because apart from unfavourable siliciclastic facies prevailing in the Polish Basin, the current species richness is four times greater than the richest Pliensbachian (Lower Jurassic) bryozoan assemblage from Germany (Voigt 1968; Illies 1971, 1973), and three times greater than the richest Upper Jurassic assemblages (Oxfordian of Normandy and Kimmeridgian of Poland) containing nine species (see Taylor \& Ernst 2008, Hara \& Taylor 2009).

The next richest bryozoan assemblage from the Polish Basin comes from the Balin Oolite in the environs of Chrzanów, southern Poland. Here 23 species of cyclostomes among the old collection of Reuss (1867) were revised by Taylor (2009). The Balin deposits are condensed Upper Bathonian/Lower Callovian (Mangold et al. 1996) or Lower-Middle Callovian (Delance et al. 1993) carbonates that are rich in shelly substrates, a very favourable facies for bryozoans.

Noticeable is the biogeographical contrast between the Bathonian cyclostome fauna of the Polish Basin and other regions. Only two species of Stomatopora (S. bajocensis and $S$. recurva) are known from the Middle Jurassic of England, France and Germany, and one species of Reptomultisparsa ( $R$. harae) is known from the Upper Bajocian of England. The rest of the species detected are either similar to other European (English) species (Reptomultisparsa aff. cobra and Hyporosopora aff. sauvagei), or are new and possibly endemic to the Polish Basin (see Zaton \& Taylor 2009a and the data presented here).

In numerical abundance, Bathonian encrusting species definitely outnumber erect species, as is a characteristic for the Jurassic as a whole, although in the Bathonian of Normandy 18 of the 33 species have erect colonies (see Taylor $\&$ Ernst 2008). Among the encrusting species described here, three colony-forms dominate: uniserial and oligoserial branching runners (Stomatopora, Proboscinopora?), multiserial sheets and spots (Microeciella, Reptomultisparsa, Hyporosopora), and dome-shaped to 'flabellotrypiform' colonies (Ceriocava). All types are characterised by different strategies in utilizing substrate space in the face of competition from other encrusters (e.g., Taylor \& Ernst 2008 and references therein). Runners are adapted for seeking spatial refuges, sheets/spots are better at defending the substrate they occupy, and domeshaped/'flabellitrypiform' colonies can utilize the third dimension by growing upward. Erect colonies (Idmonea, Mecynoecia, undetermined entalophorids) have only been found in the host sediment, and none of their attaching bases have been noticed on lithic (hiatus concretions, oncoliths) or shelly substrates. 

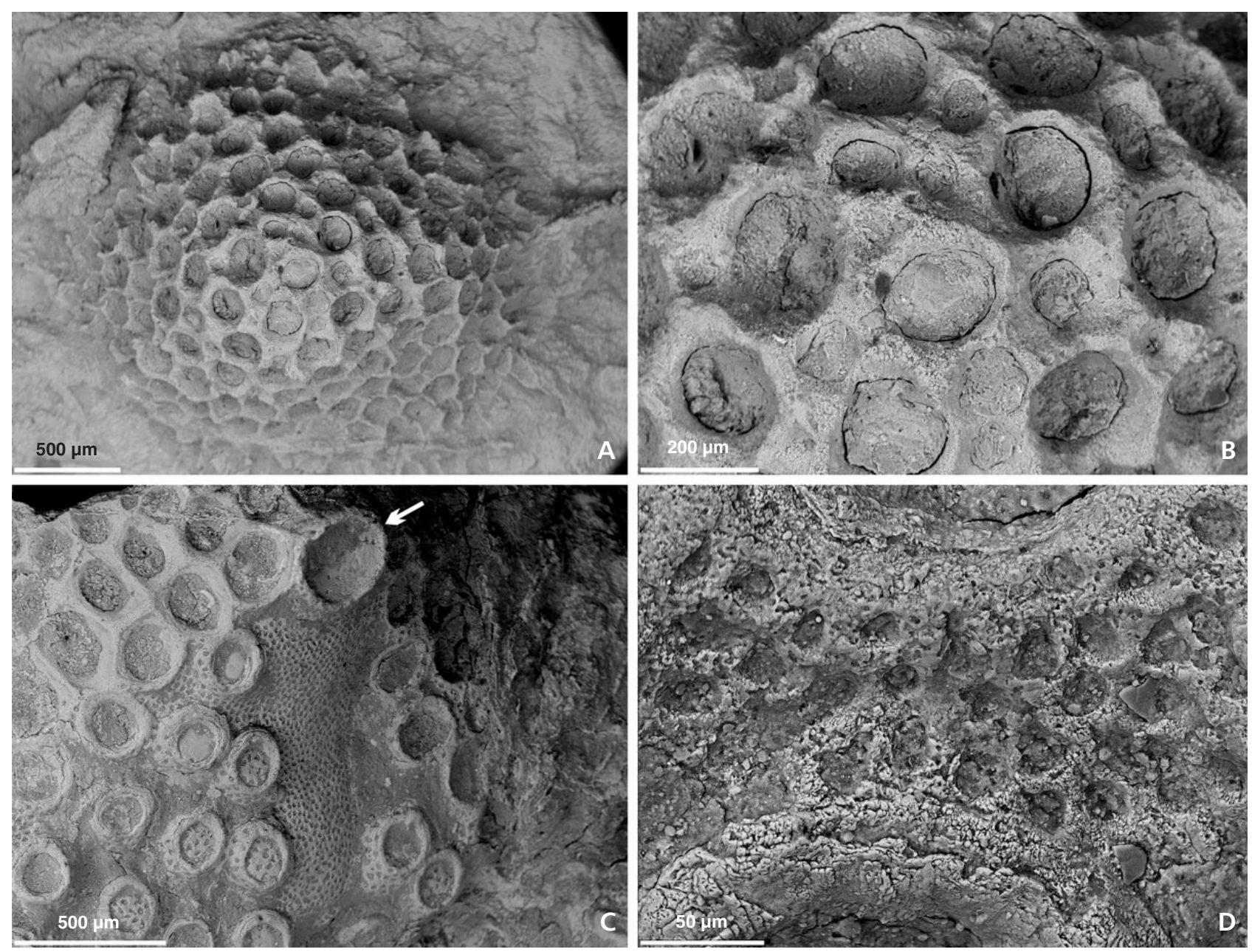

Figure 16. Ceriocava sp., Lower Bathonian, Ogrodzieniec, Polish Jura. A, B - GIUS 8-3575/1. C, D - GIUS 8-3575/2. • A - view of a cone-like colony. $\cdot \mathrm{B}$ - autozooids and interzooidal walls. $\bullet \mathrm{C}$ - gonozooid with a large ooeciopore (arrowed), associated with autozooids with both fixed-and free-walled autozooids. $\cdot \mathrm{D}-$ pseudopores.

It is worth remarking that the bryozoan assemblage composed 10 species encrusting oncoliths from Ogrodzieniec is the richest so far reported from this kind of substrate. The cyclostome assemblages reported from the Bajocian oncoliths of England and France consist of only six species (Palmer \& Wilson 1990).

\section{Acknowledgements}

We would like to thank Wojtek Krawczyński (Sosnowiec) who introduced one of us (MZ) to the outcrop with encrusted oncoliths at Ogrodzieniec and helped during their collection, and to Marek Trzepizur (Częstochowa) who donated some of the bryozoan-bearing oysters from the Gnaszyn locality for study. Andrzej Kaim (Institute of Paleobiology, Warsaw) is thanked for lending the cyclostomes from Krzyworzeka. The journal referees, Frank McKinney (Appalachian State University, USA) and Urszula Hara (Polish Geological Institute, Warsaw) gave many useful remarks and comments that improved our manuscript.

\section{References}

BARSKI, M., DEMBICZ, K. \& PRASZKIER, T. 2004. Biostratygrafia i paleośrodowisko środkowej jury z kamieniołomu Ogrodzieniec. Tomy Jurajskie 2, 61-68.

BASSLER, R.S. 1935. Bryozoa. Fossilium Catalogus, 1. Animalia 67, 1-229.

BORG, F. 1926. Studies on Recent cyclostomatous Bryozoa. Zoologiska Bidrag fran Uppsala 10, 181-507.

BRonN, H.G. 1825. System der urweltlichten Pflanzenthiere durch Diagnose, Analyse und Abbildung der Geschlechter erläutert. $47 \mathrm{pp}$. Mohr, Heidelberg.

BUSK, G. 1852. An account of the Polyzoa and Sertularian Zoophytes collected in the voyage of the Rattlesnake on the coast of Australia and the Louisiade Archipelago, 343-402. In MACGILlivrAY, J. (ed.) Narrative of the Voyage of H.M.S. Rattlesnake, commanded by the late Captain Owen Stanley, during the years 1846-1850, 1. Boone, London.

CANU, F. 1918. Les ovicelles des Bryozoaires cyclostomes. 
Études sur quelques familles nouvelles et anciennes. Bulletin de la Société géologique de France 4, 324-335.

CANU, F. \& BASSLER, R.S. 1929. Etudes sur les ovicelles des Bryozoaires jurassiques. Bulletin de la Société Linnéenne de Normandie 8, 113-131.

DADLEZ, R. 1989. Epikontynentalne baseny permu i mezozoiku w Polsce. Kwartalnik Geologiczny 33, 175-198.

DAYCZAK-CALIKOWSKA, K., KOPIK, J. \& MARCINKIEWICZ, T. 1997. Middle Jurassic, 236-282. In MAREK, S. \& PAJCHLOWA, M. (eds) Epikontynentalny perm i mezozoik $w$ Polsce. Prace Państwowego Instytutu Geologicznego 153. Wydawnictwa Geologiczne, Warszawa.

DELANCE, J.H., GARCIA, J.-P., LAURIN, B. \& TARKOWSKI, R. 1993. Les brachiopodes de 'Oolithe de Balin (Pologne). Implications stratigraphique et biogéographiques. Bulletin of the Polish Academy of Sciences, Earth Sciences 41, 169-180.

EHRENBERG, C.J. 1831. Symbolae physicae, seu icones et descriptiones mammalium, avium, insectorium et animalium evertebratorum... Pars Zoologica. 4. Animalia evertebrate exclusis insectis. Decus Primula. Berlin.

FELDMAN-OlSZEWSKA, A. 1997. Depositional architecture of the Polish epicontinental Middle Jurassic basin. Geological Quarterly 41, 491-508.

GedL, P., KAIM, A., BoCZAROWSKi, A., KęDZIERSKI, M, SMOLEŃ, J., SZCZEPANIK, P., WiTKOWSKA, M. \& ZiAJA, J. 2003. Rekonstrukcja paleośrodowiska sedymentacji środkowojurajskich iłów rudonośnych Gnaszyna (Częstochowa) wyniki wstępne. Tomy Jurajskie 1, 19-27.

GREGORY, J.W. 1896. A revision of the British Jurassic Bryozoa. Part III. The genus Berenicea. Annals and Magazine of Natural History, Series 6(17), 41-49.

HARA, U. \& TAYLOR, P.D. 1996. Jurassic bryozoans from Bałtów, Holy Cross Mountains, Poland. Bulletin of The Natural History Museum, London (Geology Series) 52, 91-102.

HARA, U. \& TAYLOR, P.D. 2009. Cyclostome bryozoans from the Kimmeridgian (Upper Jurassic) of Poland. Geodiversitas 31, 555-575.

HILLMER, G. 1968. On the variation of gonozooecia of encrusting "Berenicea"-forms (Lower Cretaceous) (Bryozoa) (Preliminary Report). Atti della Società Italiana di Scienze Naturali, e del Museo Civico di Storia Naturale. Milano 108, 64-70.

HINCKS, T. 1880. A history of the British marine Polyzoa. 601 pp. John Van Vorst, London.

ILLIES, G. 1963. Über Stomatopora dichotoma (LAMX.) und St. dichotomoides (d'ORB.) [Bryoz. Cycl.] aus dem Dogger des Oberrheingebietes. Oberrheinische Geologische Abhandlungen 12, 45-80.

ILliES, G. 1971. Drei Arten der Gattung Stomatopora [Bryoz. Cycl] aus dem mittleren Lias bei Goslar und deren verschiedene Knospungsmuster. Oberrheinische Geologische Abhandlungen 20, 125-146.

ILLIES, G. 1973. Different budding patterns in the genus Stomatopora (Bryozoa, Cyclostomata), 307-315. In LARWOOD, G.P. (ed.) Living and Fossil Bryozoa. Academic Press, London.
KOPIK, J. 1998. Jura dolna i środkowa północno-wschodniego obrzeżenia Górnosląskiego Zagłębia Węglowego. Biuletyn Państwowego Instytutu Geologicznego 378, 67-120.

KoPIK, J. 2006. Bathonian ammonites of the families Sphaeroceratidae Buckman and Tulitidae Buckman from the Polish Jura Chain (Southern Poland). Polish Geological Institute Special Papers 21, 1-68.

LAMOUROUX, J.V. 1821. Exposition méthodique des genres de l'ordre des polpiers. 115 pp. Agasse, Paris.

MCKINNEY, F.K. \& TAYLOR, P.D. 1997. Life histories of some Mesozoic encrusting cyclostome bryozoans. Palaeontology 40, 515-556.

MAJEWSKI, W. 2000. Middle Jurassic concretions from Częstochowa (Poland) as indicators of sedimentation rates. Acta Geologica Polonica 50, 431-439.

MANGOlD, C., MARChand, D., ThiERRY, J. \& TARKOWSKI, R. 1996. Les ammonites de l'oolite de Balin (Pologne): Nouvelles données et réinterprétation stratigraphique. Revue de Paléobiologie 15, 55-77.

MARYNOWSKI, L., ZATOŃ, M., SimOneIT, B.R.T., OTTO, A., JĘDRYSEK, M.-O., GRELOWSKI, C. \& KURKIEWICZ, S. 2007. Compositions, sources and depositional environments of organic matter from the Middle Jurassic clays of Poland. Applied Geochemistry 22, 2456-2485.

DO1 10.1016/j.apgeochem.2007.06.015

MATYJA, B.A. \& WIERZBOWSKI, A. 1998. Palaeogeographic evolution of the Middle-Upper Jurassic of Poland, 161-179. In Poulsen, N.E., Bojesen-Koefoed, J., Drewniak, A., GŁowniak, E., Ineson, J., Matyja, B.A., Merta, T. \& WierzBowski, A. (eds) Mellem-Øvre Jura $i$ Polen. EEP-1995 projekt: Det polske Mellem-Øvre Epikratoniske Bassin, Stratigrafi, Facies og Bassin Historie. Program Østeuropa. Danmarks og Grønlands Geologiske Undersøgelse Rapport 1998/14.

MATYJA, B.A. \& WIERZBOWSKI, A. 2000. Ammonites and stratigraphy of the uppermost Bajocian and Lower Bathonian between Częstochowa and Wieluń, Central Poland. Acta Geologica Polonica 50, 191-209.

MATYJA, B.A. \& WIERZBOWSKI, A. 2006. European Platform Middle and Upper Jurassic, 130-132. In WIERZBOWSKI, A., Aubrecht, R., GOLONKA, J., GuTOWSKI, J., KROBICKI, M., MATYJA, B.A., PIEŃKOWsKi, G. \& UChMAN, A. (eds) Jurassic of Poland and adjacent Slovakian Carpathians. Field trip guidebook of $7^{\text {th }}$ International Congress on the Jurassic System Poland, Kraków, September 6-18, 2006.

Matyja, B.A., Wierzbowski, A., GedL, P., BocZarowski, A., KAIM, A., KęDZIERSKI, M., LEONOWICZ, P., SMOLEŃ, J., SzCZEPANIK, P. \& WiTKOWSKA, M. 2006a. Stop B1.5 Sowa's and Glinski's clay pits (uppermost Bajocian-lowermost Bathonian), 149-152. In WIERZBOwSKI, A., AUBRECHT, R., GOLONKA, J., GuTOWSKI, J., KROBICKI, M., MATYJA, B.A., PIEŃKOWSKI, G. \& UCHMAN, A. (eds) Jurassic of Poland and adjacent Slovakian Carpathians. Field trip guidebook of $7^{\text {th }}$ International Congress on the Jurassic System Poland, Kraków, September 6-18, 2006.

MATYjA, B.A., Wierzbowski, A., GedL, P., BocZARowski, A., KęDZIERSKI, M., LeONOWICZ, P., SMOLEŃ, J., SZCZE- 
PANIK, P. \& WITKOWSKA, M. 2006b. Stop B1.6 Leszczyński's clay pit (Lower Bathonian), 152-154. In Wierzbowski, A., Aubrecht, R., GolonkA, J., GutowSKI, J., KRobicki, M., MATYJA, B.A., PIEŃKOWsKI, G. \& UCHMAN, A. (eds) Jurassic of Poland and adjacent Slovakian Carpathians. Field trip guidebook of $7^{\text {th }}$ International Congress on the Jurassic System Poland, Kraków, September 6-18, 2006.

MAtyja, B.A., Wierzbowski, A., GedL, P., BocZARowski, A., DUdeK, T., KAIM, A., KęDZIERSKI, M., LeONOWICZ, P., SMOLEŃ, J., SZCZEPANIK, P., WitKowsKa, M., ZiAJA, J., BARSKI, M. \& OSTROWSKI, S. 2006c. Stop B1.7 - Gnaszyn clay pit (Middle Bathonian-lowermost Upper Bathonian), 154-157. In WiERZBOWSKI, A., AUBreCHT, R., GOLONKA, J., Gutowski, J., Krobicki, M., MAtYJA, B.A., PIEŃKOWSKI, G. \& UCHMAN, A. (eds) Jurassic of Poland and adjacent Slovakian Carpathians. Field trip guidebook of $7^{\text {th }}$ International Congress on the Jurassic System Poland, Kraków, September 6-18, 2006.

MiLNE-EDWARDS, H. 1838. Mémoire sur les crisies, les hornères et plusiers autres polypes vivants ou fossiles dont l'organisation est analogue à celle des tubulipores. Annales des Sciences Naturelles. Zoologie 9, 193-238.

ORBIGNY, A. D' 1850. Prodrome de paléontologie stratigraphique universelle des animaux Mollusques et rayonnés. Tome 1. 394 pp. Masson, Paris.

ORBIGNY, A. D' 1851-1854. Paléontologie Francaise, Terrains Crétacé. 5 Bryozoaires. 1192 pp. Masson, Paris.

PALMER, T.J. \& FÜRSICH, F.T. 1981. Ecology of sponge reefs from the Upper Bathonian of Normandy. Palaeontology 24, $1-23$.

PALMER, T.J. \& WILSON, M.A. 1990. Growth of ferrugineous oncoliths in the Bajocian (Middle Jurassic) of Europe. Terra Nova 2, 142-147.

DOI 10.1111/j.1365-3121.1990.tb00055.x

PERGENS, E. \& MEUnIER, A. 1886. La faune des Bryozoaires garumniens de Faxe. Annales de la Société Royale Malacologique de Belgique 12, 181-242.

PITT, L.J. \& TAYLOR, P.D. 1990. Cretaceous Bryozoa from the Faringdon Sponge Gravel (Aptian) of Oxfordshire. Bulletin of the British Museum (Natural History), Geology Series 46, 61-152.

PITT, L.J. \& Thomas, H.D. 1969. The Polyzoa of some British Jurassic clays. Bulletin of the British Museum (Natural History), Geology Series 18, 29-38.

POHOWSKY, R.A. 1973. A Jurassic cheilostome from England, 447-461. In LARWOOD, G.P. (ed.) Living and Fossil Bryozoa. Academic Press, London.

PoulSEN, N.S. 1998. Upper Bajocian to Callovian (Jurassic) dinoflagellate cysts from central Poland. Acta Geologica Polonica 48, 237-245.

REUSS, A.E. 1867. Die Bryozoen, Anthozoen und Spongiaren des braunen Jura von Balin bei Krakau. Denkschriften der Kaiserlichen Akademie der Wissenschaften, Wien, mathematisch-naturwissenschaftliche Klasse 27, 1-26.

REUSS, A.E. 1869. Palaontologischen Studien uber die alteren Tertiarschichten der Alpen. II. Abtheilung. Die Fossilen
Anthozoen und Bryozoen der Schichtengruppe von Crosara. Denkschriften der Kaiserlichen Akademie der Wissenschaften, Wien, mathematisch- naturwissenschaftliche Klasse 29, 215-298.

RÓŻYCKI, S.Z. 1953. Górny dogger i dolny malm Jury Krakowsko-Częstochowskiej. Prace Instytutu Geologicznego $17,1-420$.

SzCZEPANIK, P., WitKowska, M. \& SAwŁowicz, Z. 2007. Geochemistry of Middle Jurassic mudstones (Kraków-Częstochowa area, southern Poland): interpretation of the depositional redox conditions. Geological Quarterly 51, 57-66.

TAYLOR, P.D. 1994. Evolutionary palaeoecology of symbioses between bryozoans and hermit crabs. Historical Biology 9, 157-205. DOI 10.1080/10292389409380497

TAYLOR, P.D. 2009. Bryozoans from the Middle Jurassic of Balin, Poland: a revision of material described by A.E. Reuss (1867). Annalen des Naturhistorischen Museums in Wien, Serie A 110A, 17-54.

TAYLOR, P.D. \& ERNST, A. 2008. Bryozoans in transition: the depauperate and patchy Jurassic biota. Palaeogeography, Palaeoclimatology, Palaeoecology 263, 9-23. DOI 10.1016/j.palaeo.2008.01.028

TAYLOR, P.D. \& MCKInNEY, F.K. 2006. Cretaceous Bryozoa from the Campanian and Maastrichtian of the Atlantic and Gulf Coastal Plains, United States. Scripta Geologica 132, $1-346$.

TAYLOR, P.D. \& SEQUEIROS, L. 1982. Toarcian bryozoans from Belchite in north-east Spain. Bulletin of the British Museum (Natural History), Geology Series 37, 117-129.

TAYLOR, P.D. \& WILSON, M.A. 1999. Middle Jurassic bryozoans from the Carmel Formation of southwestern Utah. Journal of Paleontology 73, 816-830.

TAYLOR, P.D. \& ZATON, M. 2008. Taxonomy of the bryozoan genera Oncousoecia, Microeciella and Eurystrotos (Cyclostomata: Oncousoeciidae). Journal of Natural History 42, 2557-2574. DOI 10.1080/00222930802277640

VINE, G.R. 1893. Notes on the Polyzoa, Stomatopora and Proboscina groups, from the Cornbrash of Thrapston, Northamptonshire. Proceedings of the Yorkshire Geological and Polytechnic Society, New Series 12, 247-258.

VISKOVA, L.A. 2009. New species of stenolaemate bryozoans from the Jurassic of the Moskov and Saratov regions (Russia). Paleontological Journal 43, 408-417.

DOI 10.1134/S003103010904008X

VOIGT, E. 1968. Über Hiatus-Konkretionen (dargestellt an Beispielen aus dem Lias). Geologische Rundschau 58, 281-296. DO] 10.1007/BF01820609

WALTER, B. 1967. Revision de la faune de bryozoaires du Bajocien Superieur de Shipton Gorge (Dorset, GrandeBretagne). Travaux des Laboratoires de Géologie de la Faculté des Sciences de Lyon, N.S. 14, 43-52.

WALTER, B. 1970. Les bryozoaires jurassiques en France. Documents des Laboratoires de Géologie de la Faculté des Sciences de Lyon 35 [for 1969], 1-328.

ZATOŃ, M. 2007. Amonity z iłów rudonośnych (bajos-baton) Jury Polskiej. 521 pp. Unpublished Ph.D. thesis, University of Silesia, Sosnowiec. 
ZATOŃ, M. \& MARYNOWSKI, L. 2006. Ammonite fauna from uppermost Bajocian (Middle Jurassic) calcitic concretions from the Polish Jura - biogeographical and taphonomical implications. Geobios 39, 426-442.

DO1 10.1016/j.geobios.2005.02.001

ZATON, M. \& TAYLOR, P.D. 2009a. Middle Jurassic cyclostome bryozoans from the Polish Jura. Acta Palaeontologica Polonica 54, 267-288. DOI 10.4202/app.2008.0088

ZATON, M. \& TAYLOR, P.D. 2009b. Microconchids (Tentaculita) from the Middle Jurassic of Poland. Bulletin of Geosciences $84,653-660$.

ZATOŃ, M., MARYNOWSKI, L. \& BZOWSKA, G. 2006a. Konkrecje hiatusowe z iłów rudonośnych Wyżyny KrakowskoCzęstochowskiej. Przegląd Geologiczny 54, 131-138.

ZATOŃ, M., BARBACKA, M., MARYNOWSKI, L. \& KRZYSTANEK,
J. 2006b. Sagenopteris (Caytoniales) with its possible preserved biomarkers from the Bathonian of the Polish Jura, south-central Poland. Neues Jahrbuch für Geologie und Paläontologie, Monatshefte 7, 385-402.

ZATOŃ, M., VillieR, L. \& SAlAMON, M.A. 2007. Signs of predation in the Middle Jurassic of south-central Poland: evidence from echinoderm taphonomy. Lethaia 40, 139-151.

ZATOŃ, M., MARYNOWSKI, L., SZCZEPANIK, P., BOND, D.P.G. \& WignaLL, P.B. 2009. Redox conditions during sedimentation of the Middle Jurassic (Upper Bajocian-Bathonian) clays of the Polish Jura (south-central Poland). Facies 55, 103-114. DO1 10.1007/s10347-008-0159-Z

ZIEGLER, P.A. 1990. Geological atlas of western and central Europe. $239 \mathrm{pp}$. Shell Internationale Petroleum Maatschappij B.V., London. 